\title{
Data paper: FoRAGE (Functional Responses from Around the Globe in all \\ Ecosystems) database: a compilation of functional responses for consumers and
}

\section{parasitoids}

\author{
Stella F. Uiterwaal, Ian T. Lagerstrom, Shelby R. Lyon, John P. DeLong \\ School of Biological Sciences, University of Nebraska - Lincoln, Lincoln, NE 68588 USA
}

\section{$\underline{\text { ABSTRACT }}$}

Functional responses - the relationships between consumer foraging rate and resource (prey) density - provide key insights into consumer-resource interactions and predation mechanics while also being a major contributor to population dynamics and food web structure. We present a global database of standardized functional response parameters extracted from the published literature. We refit the functional responses with a Type II model using standardized methods and report the fitted parameters along with data on experimental conditions, consumer and resource taxonomy and type, as well as the habitat and dimensionality of the foraging interaction. The consumer and resource species covered here are taxonomically diverse, from protozoans filtering algae to wasps parasitizing moth larvae to wolves hunting moose. The FoRAGE database (doi:10.5063/F17H1GTQ) is a living data set that will be updated periodically as new functional responses are published.

\section{INTRODUCTION}

The strength of a consumer-resource interaction determines the importance of a given food web link (Novak and Wootton, 2010). Thus, interaction strength can give key insights into population dynamics and the structure and stability of food webs (Gilbert et al., 2014; McCann et al., 1998). 
One way to measure consumer-resource interaction strength is through the functional response (Holling, 1959a). A consumer's functional response describes foraging rate as a function of resource availability. The simplest form is Type I, where foraging increases linearly with resource density. Most consumers, however, must pay a time cost for each resource item utilized, resulting in an asymptotic, Type II functional response. A common form of Type II functional response is the Holling disc equation:

$$
f_{p c}=\frac{a R}{1+a R h} \quad \text { Equation } 1 .
$$

where $f_{p c}$ is the per capita foraging rate of the consumer (number of resources per time per predator), $a$ is the space clearance rate (space per time per predator), $R$ is the initial resource density (resources per space), and $h$ is handling time (time per resource) (Holling, 1959a). Space clearance rate describe how quickly a consumer can remove resources from a given space, while handling time describes the loss in search time associated with the consumption of an individual resource item. Handling time reflects any actcivity that prevents the consumer from searching for additional resources (prey items) after catching a resource. This may include transporting the resource to a safe location, chewing the resource, and any time spent digesting (if the consumer cannot continue hunting while digesting).

Here, we present standardized functional response parameters and the associated experimental conditions for over 2,000 consumer-resource combinations from the literature. The database will be periodically revised and updated with new functional responses as they are published. The data set is housed at the Knowledge Network for Biocomplexity (https://knb.ecoinformatics.org/) and can be found through its DOI: doi:10.5063/F17H1GTQ. The data set contains two files, one containing the overall data set of functional response parameters 
and associated information (with 'data set' in the file name) and the other containing the raw foraging observations (with 'original curves' in the file name).

\section{METHODS}

We searched the literature using terms such as "functional response", "predator-prey interaction", and "biocontrol" to find papers reporting predator and parasitoid functional responses. We also searched within references of papers that contained functional responses, through other compilations of functional responses (DeLong et al., 2015; DeLong and Vasseur, 2012a, 2012b, 2011; Kalinoski and DeLong, 2016; Rall et al., 2012; Uiterwaal and DeLong, 2018), and through the websites of researchers that had done multiple functional response papers. Our search produced 2,083 functional responses across a wide range of taxa from all habitats and biomes and from around the world. See Appendix A for sources. Each individual functional response curve received a unique ID number associated with its functional response data, consumer and resource traits, and experimental conditions. Multiple distinct curves - due to experimental treatments, age and/or sex, consumer and/or resource species, temperature, number of consumers, substrate, or other category - from the same paper received different IDs.

\section{Functional response data}

\section{$\underline{\text { Data collection }}$}

Due to discrepancies in terms of equations and techniques used to calculate functional responses across studies, species, and experimental approaches, we did not use the parameters reported in the original papers. Rather, we recorded original resource density and consumer foraging rate data as given in the paper. We preferentially recorded raw data in tables, but we digitized most data from figures. When raw data was not available, we recorded mean foraging rate at a given resource 
density along with standard errors and sample size at that density. We converted error bars presented as $95 \%$ confidence intervals or standard deviation to standard error. In some cases where raw data was reported in figures, it was unclear how many actual observations were represented by a point on the graph. In these cases, we used the minimum possible number of replicates based on the reported sample size to obtain a conservative number of datapoints. If resource density was expressed in terms of carbon, protein, or chlorophyll concentration, we converted this to number of individuals using conversions provided in the paper (preferentially) or from outside sources. The data collection process is outlined in Figure 1. Additional functional response data can be included in the FoRAGE data set by making the corresponding author aware of a new source via email.

\section{$\underline{\text { Data fitting }}$}

We made all data comparable by standardizing resource density to units of resources per $\mathrm{cm}^{2}$ or $\mathrm{m}^{2}$ or resources per $\mathrm{cm}^{3}$ or $\mathrm{m}^{3}$ and foraging rate to units of number of resources eaten (or parasitized) per consumer per day. For 2.5-dimensional foragers (See "Experimental conditions" below), we rescaled prey density by raising it to the power of $2.5 / 2$ if density was reported as an area and to the power of $2.5 / 3$ if density was reported as a volume. In this way, the units of space clearance rate for organisms foraging in a fractal dimension between a plane and a volume are $\mathrm{m}^{2.5}$ per predator per day. However, the prey density data are retained in either two or three dimensional units within the 'original curves' file.

We generated 200 bootstrapped datasets per functional response. We used standard ransom sampling with replacement for data sets with raw data. For data sets that reported mean foraging rate at different densities, we generated simulated data sets with the same mean, standard error, 
and sample size as the reported data set using the same bootstrapping procedure. Then, we fit foraging data to the Holling disc equation (Equation 1) if the resource was replenished by the experimenters as it was consumed throughout the experiment. Datasets from wild consumers were treated as having resources replenished. If resources were not replenished, we fit foraging data to the Roger's random predator equation:

$$
f_{p c}=R-\frac{W\left(a h R e^{-a(t-h R)}\right)}{a h} \quad \text { Equation } 2 .
$$

where $f_{p c}$ is the per capita number of resources eaten by the consumer in the time of the foraging trial $t, W$ is the Lambert $\mathrm{W}$ function, and $R, a$, and $h$ are as in Equation 1. This equation accounts for resource depletion as the consumer forages (Bolker, 2008; Rogers, 1972). We used nonlinear ordinary least squares regression in Matlab to conduct these fits. To obtain parameter estimates and confidence intervals, we used the medians and $95 \%$ quantiles of the bootstrapped parameter distributions, respectively. We did not account for prey or predator population growth in the fitting procedure (Rosenbaum and Rall, 2018), although most experiments were conducted for periods precluding changes in prey or predator through reproduction.

When sample size was not given for data presented as means, we assumed conservatively that there were three replicates, the minimum number required to obtain a standard error. To estimate error when none was given or when error type was not specified, we used a Taylor power law relationship between the mean and the foraging rate variance across all observations in the data set for which this was available. We estimated this relationship using ordinary least squares regression with the log of the standard error as the dependent variable and the log of the mean foraging rate as the independent variable (Figure 2). The fitted exponent was $0.83(0.006 \pm \mathrm{SE})$ and the intercept was $-1.76( \pm 0.028)$. When arena size was not given, we conducted the fits and reported the handling time in the standard units but space clearance rate with units of 'arenas per 
predator per day'. If handling time was not different from zero (95\% confidence intervals overlapped zero), the functional response was assumed to be Type I and handling time was removed.

\section{Consumer and resource traits}

$\underline{\text { Mass }}$

We recorded masses or lengths of consumer and resource species from the original papers if available. If size measurements were not available in the original paper, we used mass or length estimates from external sources. We converted lengths to masses using length-weight relationships (usually by order or family). When no species-level size estimates were available, we calculated size based on one or more closely related species (e.g., in the same genus). In some cases, we were unable to obtain sizes of juveniles. In these cases, we calculated juvenile:adult size ratios of a related organism for which we did have juvenile size data. We used this percentage to estimate the unknown juvenile size of the focal organism. When necessary, we used water content to calculate wet mass from dry mass. Because predators and parasitoids utilize live resources, wet mass provides a more accurate size estimate than dry mass for functional response experiments. We used volume estimates and the density of freshwater or saltwater to estimate masses of some aquatic organisms (e.g. single-celled algae). Our methods for recording consumer and resource masses are outlined in Figure 3.

\section{$\underline{\text { Other traits }}$}

We recorded consumer and resource traits as reported in the paper, including developmental stage, sex, and interaction type (predation or parasitoidism). We also assigned each consumer and 
resource to approximate taxonomic categories, including their level of cellularity (unicell or metazoan), vertebrate status (vertebrate, invertebrate, or protozoan), and other levels that represented major groupings of data such as 'fish' or 'copepod' or 'dinoflagellate'.

\section{$\underline{\text { Experimental conditions }}$}

We recorded temperature or average temperature (if a range was given) at which experiments with ectotherms were conducted. If the consumer was an endotherm, we recorded body temperature. We also reported the number of consumers per arena and the length of time consumers were deprived of resources before the experiment. We recorded notes on other experimental variables such as habitat complexity or chemical pretreatment of organisms. We also identified fielddetermined functional responses as ones where consumers were foraging in natural field settings rather than in a laboratory.

We determined whether the functional response occurred in two-dimensional (e.g. wolf spiders in a petri dish), three-dimensional (e.g. copepods and Daphnia in a tank), or 2.5dimensional (e.g. insects crawling on whole plants, spiders on webs) space. In cases where the consumer moved in three dimensions but the resource moved in two dimensions (e.g. fish consuming bottom-dwelling crayfish), we determined the interaction to be occurring in two dimensions.

\section{ACKNOWLEDGEMENTS}

This work was supported by a James S. McDonnell Foundation Complex Systems Scholar Award to J.P.D., a Binational Science Foundation (BSF) grant (number 2014295), and a National Science Foundation Graduate Research Fellowship to S.F.U (DGE-1610400). 


\section{REFERENCES}

Agarwala, B.K., Bardhanroy, P., Yasuda, H., Takizawa, T., 2001. Prey Consumption and Oviposition of the Aphidophagous Predator Menochilus sexmaculatus (Coleoptera: Coccinellidae) in Relation to Prey Density and Adult Size. Environ Entomol 30, 1182-1187. https://doi.org/10.1603/0046225X-30.6.1182

Akre, B.G., Johnson, D.M., 1979. Switching and Sigmoid Functional Response Curves by Damselfly Naiads with Alternative Prey Available. Journal of Animal Ecology 48, 703-720. https://doi.org/10.2307/4191

Alanis, J.G., Sarma, S.S.S., Nandini, S., 2009. Prey selectivity and functional response by larval red-eyed tetra Moenkhausia sanctaefilomenae (Steindachner, 1907) (Characiformes: Characidae). Brazilian Archives of Biology and Technology 52, 1209-1216. https://doi.org/10.1590/S151689132009000500019

Alexander, M.E., Dick, J.T.A., O'Connor, N.E., 2013a. Born to kill: Predatory functional responses of the littoral amphipod Echinogammarus marinus Leach throughout its life history. Journal of Experimental Marine Biology and Ecology 439, 92-99. https://doi.org/10.1016/j.jembe.2012.10.006

Alexander, M.E., Dick, J.T.A., O'Connor, N.E., 2013b. Trait-mediated indirect interactions in a marine intertidal system as quantified by functional responses. Oikos 122, 1521-1531. https://doi.org/10.1111/j.1600-0706.2013.00472.x

Alexander, M.E., Dick, J.T.A., O’Connor, N.E., Haddaway, N.R., Farnsworth, K.D., 2012. Functional responses of the intertidal amphipod Echinogammarus marinus: effects of prey supply, model selection and habitat complexity. Marine Ecology Progress Series 468, 191-202. https://doi.org/10.3354/meps09978

Alexander, M.E., Dick, J.T.A., Weyl, O.L.F., Robinson, T.B., Richardson, D.M., 2014. Existing and emerging high impact invasive species are characterized by higher functional responses than natives. Biol Lett 10. https://doi.org/10.1098/rsbl.2013.0946

Alexander, M.E., Kaiser, H., Weyl, O.L.F., Dick, J.T.A., 2015. Habitat simplification increases the impact of a freshwater invasive fish. Environ Biol Fish 98, 477-486. https://doi.org/10.1007/s10641-0140278-z

Aljetlawi, A.A., Sparrevik, E., Leonardsson, K., 2004. Prey-predator size-dependent functional response: derivation and rescaling to the real world. Journal of Animal Ecology 73, 239-252. https://doi.org/10.1111/j.0021-8790.2004.00800.x

Almeda, R., Augustin, C.B., Alcaraz, M., Calbet, A., Saiz, E., 2010. Feeding rates and gross growth efficiencies of larval developmental stages of Oithona davisae (Copepoda, Cyclopoida). Journal of Experimental Marine Biology and Ecology 387, 24-35. https://doi.org/10.1016/j.jembe.2010.03.002

Anderson, R.M., Whitfield, P.J., Dobson, A.P., Keymer, A.E., 1978. Concomitant Predation and Infection Processes: An Experimental Study. Journal of Animal Ecology 47, 891-911. https://doi.org/10.2307/3677

Anderson, T.L., 2016. Predation risk between cannibalistic aeshnid dragonflies influences their functional response on a larval salamander prey. Journal of Zoology 300, 221-227. https://doi.org/10.1111/jzo.12376

Anderson, T.L., Linares, C., Dodson, K.N., Semlitsch, R.D., 2016. Variability in functional response curves among larval salamanders: comparisons across species and size classes. Canadian Journal of Zoology 94, 23-30. https://doi.org/10.1139/cjz-2015-0149

Anderson, T.W., 2001. Predator Responses, Prey Refuges, and Density-Dependent Mortality of a Marine Fish. Ecology 82, 245-257. https://doi.org/10.1890/0012-9658(2001)082[0245:PRPRAD]2.0.CO;2 
Andresen, H., van der Meer, J., 2010. Brown shrimp (Crangon crangon, L.) functional response to density of different sized juvenile bivalves Macoma balthica (L.). Journal of Experimental Marine Biology and Ecology 390, 31-38. https://doi.org/10.1016/j.jembe.2010.04.027

Asante, S.K., 1995. Functional Responses of the European Earwig and Two Species of Coccinellids to Densities of Eriosoma lanigerum (Hausmann) (Hemiptera: Aphididae). Australian Journal of Entomology 34, 105-109. https://doi.org/10.1111/j.1440-6055.1995.tb01295.x

Atlihan, R., Kaydan, M.B., Yarimbatman, A., Okut, H., 2010. Functional response of the coccinellid predator Adalia fasciatopunctata revelierei to walnut aphid (Callaphis juglandis) | SpringerLink. Phytoparastica 38, 23-29.

Badii, M.H., Hernández-Ortiz, E., Flores, A.E., Landeros, J., 2004. Prey stage preference and functional response of Euseius hibisci to Tetranychus urticae (Acari: Phytoseiidae, Tetranychidae). Exp. Appl. Acarol. 34, 263-273.

Bailey, K.M., Batty, R.S., 1983. A laboratory study of predation by Aurelia aurita on larval herring (Clupea harengus): Experimental observations compared with model predictions. Marine Biology 72, 295-301. https://doi.org/10.1007/BF00396835

Bailey, P.C.E., 1989. The effect of water temperature on the functional response of the water stick insect Ranatra dispar (Heteroptera: Nepidae). Australian Journal of Ecology 14, 381-386. https://doi.org/10.1111/j.1442-9993.1989.tb01448.x

Ball, S.L., Woodcock, B.A., Potts, S.G., Heard, M.S., 2015. Size matters: Body size determines functional responses of ground beetle interactions. Basic and Applied Ecology 16, 621-628. https://doi.org/10.1016/j.baae.2015.06.001

Båmstedt, U., 1998. Trophodynamics of Pleurobrachia pileus (Ctenophora, Cydippida) and ctenophore summer occurrence off the Norwegian North-West coast. Sarsia 83, 169-181. https://doi.org/10.1080/00364827.1998.10413680

Båmstedt, U., 1990. Trophodynamics of the scyphomedusae Aurelia aurita. Predation rate in relation to abundance, size and type of prey organism. J Plankton Res 12, 215-229. https://doi.org/10.1093/plankt/12.1.215

Båmstedt, U., Martinussen, M.B., Matsakis, S., 1994. Trophodynamics of the two scyphozoan jellyfishes, Aurelia aurita and Cyanea capillata, in western Norway. ICES J Mar Sci 51, 369-382. https://doi.org/10.1006/jmsc.1994.1039

Barbosa, P.R.R., Oliveira, M.D., Giorgi, J.A., Silva-Torres, C.S.A., Torres, J.B., 2014. Predatory Behavior and Life History of Tenuisvalvae notata (Coleoptera: Coccinellidae) Under Variable Prey Availability Conditions. Florida Entomologist 97, 1026-1034. https://doi.org/10.1653/024.097.0304

Barnhisel, D.R., Kerfoot, W.C., 2004. Fitting into Food Webs: Behavioral and Functional Response of Young Lake Trout (Salvelinus namaycush) to an Introduced Prey, the Spiny Cladoceran (Bythotrephes cederstroemi). Journal of Great Lakes Research 30, 300-314. https://doi.org/10.1016/S0380-1330(04)70393-7

Barrios-O'Neill, D., Dick, J.T.A., Emmerson, M.C., Ricciardi, A., Maclsaac, H.J., Alexander, M.E., Bovy, H.C., 2014. Fortune favours the bold: a higher predator reduces the impact of a native but not an invasive intermediate predator. Journal of Animal Ecology 83, 693-701. https://doi.org/10.1111/1365-2656.12155

Beier, S., Bolley, M., Traunspurger, W., 2004. Predator-prey interactions between Dugesia gonocephala and free-living nematodes. Freshwater Biology 49, 77-86. https://doi.org/10.1046/j.13652426.2003.01168.x

Bergman, E., 1988. Foraging Abilities and Niche Breadths of Two Percids, Perca fluviatilis and Gymnocephalus cernua, Under Different Environmental Conditions. Journal of Animal Ecology 57, 443-453. https://doi.org/10.2307/4916 
Bergman, E., 1987. Temperature-dependent differences in foraging ability of two percids, Perca fluviatilis and Gymnocephalus cernuus. Environ Biol Fish 19, 45-53. https://doi.org/10.1007/BF00002736

Bergström, U., Englund, G., 2004. Spatial scale, heterogeneity and functional responses. Journal of Animal Ecology 73, 487-493. https://doi.org/10.1111/j.0021-8790.2004.00823.x

Bolker, B.M., 2008. Ecological Models and Data in R. Princeton University Press.

Bollache, L., Dick, J.T., Farnsworth, K.D., Montgomery, W.I., 2008. Comparison of the functional responses of invasive and native amphipods. Biol Lett 4, 166-169. https://doi.org/10.1098/rsbl.2007.0554

Bovy, H.C., Barrios-O'Neill, D., Emmerson, M.C., Aldridge, D.C., Dick, J.T.A., 2015. Predicting the predatory impacts of the "demon shrimp" Dikerogammarus haemobaphes, on native and previously introduced species. Biol Invasions 17, 597-607. https://doi.org/10.1007/s10530-0140751-9

Brandl, Z., 1998. Feeding strategies of planktonic cyclopoids in lacustrine ecosystems. Journal of Marine Systems 15, 87-95. https://doi.org/10.1016/S0924-7963(97)00042-0

Bressendorff, B.B., Toft, S., 2011. Dome-shaped functional response induced by nutrient imbalance of the prey. Biol Lett 7, 517-520. https://doi.org/10.1098/rsbl.2011.0103

Bryan, M.D., Atchison, G.J., Sandheinrich, M.B., 1995. Effects of cadmium on the foraging behavior and growth of juvenile bluegill, Lepomis macrochirus. Can. J. Fish. Aquat. Sci. 52, 1630-1638. https://doi.org/10.1139/f95-757

Buckel, J.A., Stoner, A.W., 2000. Functional response and switching behavior of young-of-the-year piscivorous bluefish. Journal of Experimental Marine Biology and Ecology 245, 25-41. https://doi.org/10.1016/S0022-0981(99)00155-0

Buecher, E., Gasser, B., 1998. Estimation of predatory impact of Pleurobrachia rhodopis (cydippid ctenophore) in the northwestern Mediterranean Sea: in situ observations and laboratory experiments. J Plankton Res 20,631-651. https://doi.org/10.1093/plankt/20.4.631

Burns, C.W., Rigler, F.H., 1967. Comparison of Filtering Rates of Daphnia Rosea in Lake Water and in Suspensions of Yeast. Limnology and Oceanography 12, 492-502. https://doi.org/10.4319/lo.1967.12.3.0492

Buskey, E.J., Coulter, C.J., Brown, S.L., 1994. Feeding, growth and bioluminescence of the heterotrophic dinoflagellate Protoperidinium huberi. Marine Biology 121, 373-380. https://doi.org/10.1007/BF00346747

Cabral, S., Soares, A.O., Garcia, P., 2009. Predation by Coccinella undecimpunctata L. (Coleoptera: Coccinellidae) on Myzuspersicae Sulzer (Homoptera: Aphididae): Effect of prey density. Biological Control 50, 25-29. https://doi.org/10.1016/j.biocontrol.2009.01.020

Carrillo, D., Peña, J.E., 2012. Prey-stage preferences and functional and numerical responses of Amblyseius largoensis (Acari: Phytoseiidae) to Raoiella indica (Acari: Tenuipalpidae). Exp Appl Acarol 57, 361-372. https://doi.org/10.1007/s10493-011-9488-7

Castagnoli, M., Simoni, S., 1999. Effect of long-term feeding history on functional and numerical response of Neoseiulus californicus (Acari: Phytoseiidae). Exp Appl Acarol 23, 217-234. https://doi.org/10.1023/A:1006066930638

Cédola, C.V., Sánchez, N.E., Liljesthröm, G.G., 2001. Effect of Tomato Leaf Hairiness on Functional and Numerical Response of Neoseiulus Californicus (Acari: Phytoseiidae). Exp Appl Acarol 25, 819831. https://doi.org/10.1023/A:1020499624661

Chang, K.-S., Morimoto, N., Nakasuji, F., 1993. The functional response of a coccinellid beetle Aiolocaria hexaspilota to its prey, the Walnut Leaf Beetle Gastrolina depressa. Chinese Journal of Entomology 13, 187-193. 
Chant, D.A., 1961. The Effect of Prey Density on Prey Consumption and Oviposition in Adults of Typhlodromus (t.) occidentalis Nesbitt (acarina: Phytoseiidae) in the Laboratory. Can. J. Zool. 39, 311-315. https://doi.org/10.1139/z61-035

Chenaux, B., Costamagna, A.C., Bianchi, F.J.J.A., Schellhorn, N.A., 2011. Functional response of two common Australian predators, Dicranolaius bellulus (Guérin-Méneville) (Coleoptera: Melyridae) and Micraspis frenata (Erichson) (Coleoptera: Coccinellidae), attacking Aphis gossypii Glover (Hemiptera: Aphididae). Australian Journal of Entomology 50, 453-459. https://doi.org/10.1111/j.1440-6055.2011.00830.x

Chesson, J., 1989. The Effect of Alternative Prey on the Functional Response of Notonecta hoffmani. Ecology 70, 1227-1235. https://doi.org/10.2307/1938180

Chigbu, P., Sibley, T.H., 1994. Predation by Neomysis mercedis: effects of temperature, Daphnia magna size and prey density on ingestion rate and size selectivity. Freshwater Biology 32, 39-48. https://doi.org/10.1111/j.1365-2427.1994.tb00864.x

Chong, J.-H., Oetting, R.D., 2006. Functional response and progeny production of the Madeira mealybug parasitoid, Anagyrus sp. nov. nr. sinope: The effects of host and parasitoid densities. Biological Control 39, 320-328. https://doi.org/10.1016/j.biocontrol.2006.08.013

Chow, T., Long, G.E., Tamaki, G., 1983. Effects of Temperature and Hunger on the Functional Response of Geocoris bullatus (Say) (Hemiptera: Lygaeidae) to Lygus spp. (Hemiptera: Miridae) Density. Environ Entomol 12, 1332-1338. https://doi.org/10.1093/ee/12.5.1332

Claver, M.A., Ravichandran, B., Khan, M.M., Ambrose, D.P., 2003. Impact of cypermethrin on the functional response, predatory and mating behaviour of a non-target potential biological control agent Acanthaspis pedestris (Stål) (Het., Reduviidae). Journal of Applied Entomology 127, 18-22. https://doi.org/10.1046/j.1439-0418.2003.00654.x

Colin, S.P., Dam, H.G., 2007. Comparison of the functional and numerical responses of resistant versus non-resistant populations of the copepod Acartia hudsonica fed the toxic dinoflagellate Alexandrium tamarense. Harmful Algae 6, 875-882. https://doi.org/10.1016/j.hal.2007.05.003

Coll, M., Ridgway, R.L., 1995. Functional and Numerical Responses of Orius insidiosus (Heteroptera: Anthocoridae) to Its Prey in Different Vegetable Crops. Ann Entomol Soc Am 88, 732-738. https://doi.org/10.1093/aesa/88.6.732

Confer, J.L., 1971. Intrazooplankton Predation by Mesocyclops edax at Natural Prey Densities. Limnology and Oceanography 16, 663-666. https://doi.org/10.4319/lo.1971.16.4.0663

Cothran, M.L., Thorp, J.H., 1985. Tests of Preference and Switching Behavior of the Dragonfly Celithemis fasciata. Oikos 44, 350-355. https://doi.org/10.2307/3544710

Cowan, Z.-L., Dworjanyn, S.A., Caballes, C.F., Pratchett, M.S., 2016. Predation on crown-of-thorns starfish larvae by damselfishes. Coral Reefs 35, 1253-1262. https://doi.org/10.1007/s00338016-1491-3

Crowley, P.H., Martin, E.K., 1989. Functional Responses and Interference within and between Year Classes of a Dragonfly Population. Journal of the North American Benthological Society 8, 211221. https://doi.org/10.2307/1467324

Czesny, S., Dabrowski, K., Frankiewicz, P., 2001. Foraging patterns of juvenile walleye (Stizostedion vitreum) in a system consisting of a single predator and two prey species: testing model predictions. Can. J. Zool. 79, 1394-1400. https://doi.org/10.1139/z01-087

Dale, B.W., Adams, L.G., Bowyer, R.T., 1994. Functional response of wolves preying on barren-ground caribou in a multiple-prey ecosystem. Journal of Animal Ecology 63, 9. https://doi.org/10.2307/5230

Daly, B., Long, W.C., 2014. Inter-Cohort Cannibalism of Early Benthic Phase Blue King Crabs (Paralithodes platypus): Alternate Foraging Strategies in Different Habitats Lead to Different Functional Responses. PLOS ONE 9, e88694. https://doi.org/10.1371/journal.pone.0088694 
De Clercq, P., Merlevede, F., Mestdagh, I., Vandendurpel, K., Mohaghegh, J., Degheele, D., 1998. Predation on the tomato looper Chrysodeixis chalcites (Esper) (Lep., Noctuidae) by Podisus maculiventris (Say) and Podisus nigrispinus (Dallas) (Het., Pentatomidae). Journal of Applied Entomology 122, 93-98. https://doi.org/10.1111/j.1439-0418.1998.tb01468.x

De Clercq, P., Mohaghegh, J., Tirry, L., 2000. Effect of Host Plant on the Functional Response of the Predator Podisus nigrispinus (Heteroptera: Pentatomidae). Biological Control 18, 65-70. https://doi.org/10.1006/bcon.1999.0808

de Figueiredo, G.M., Nash, R.D.M., Montagnes, D.J.S., 2007. Do protozoa contribute significantly to the diet of larval fish in the Irish Sea? Journal of the Marine Biological Association of the United Kingdom 87, 843-850. https://doi.org/10.1017/S002531540705713X

de Villemereuil, P.B., López-Sepulcre, A., 2011. Consumer functional responses under intra- and interspecific interference competition. Ecological Modelling 222, 419-426. https://doi.org/10.1016/j.ecolmodel.2010.10.011

DeBlois, E.M., Leggett, W.C., 1991. Functional response and potential impact of invertebrate predators on benthic fish eggs: analysis of the Calliopius laeviusculus-capelin (Mallotus villosus) predatorprey system. Marine Ecology Progress Series 69, 205-216.

DeLong, J.P., Gilbert, B., Shurin, J.B., Savage, V.M., Barton, B.T., Clements, C.F., Dell, A.I., Greig, H.S., Harley, C.D.G., Kratina, P., McCann, K.S., Tunney, T.D., Vasseur, D.A., O'Connor, M.I., 2015. The body size dependence of trophic cascades. Am. Nat. 185, 354-366. https://doi.org/10.1086/679735

DeLong, J.P., Vasseur, D.A., 2012a. A dynamic explanation of size-density scaling in carnivores. Ecology 93, 470-476. https://doi.org/10.1890/11-1138.1

DeLong, J.P., Vasseur, D.A., 2012b. Size-density scaling in protists and the links between consumerresource interaction parameters. J Anim Ecol 81, 1193-1201. https://doi.org/10.1111/j.13652656.2012.02013.x

DeLong, J.P., Vasseur, D.A., 2011. Mutual interference is common and mostly intermediate in magnitude. BMC Ecology 11, 1. https://doi.org/10.1186/1472-6785-11-1

DeMott, W.R., 1982. Feeding selectivities and relative ingestion rates of Daphnia and Bosmina. Limnology and Oceanography 27, 518-527. https://doi.org/10.4319/lo.1982.27.3.0518

Denno, R.F., Gratton, C., Döbel, H., Finke, D.L., 2003. Predation Risk Affects Relative Strength of Topdown and Bottom-up Impacts on Insect Herbivores. Ecology 84, 1032-1044. https://doi.org/10.1890/0012-9658(2003)084[1032:PRARSO]2.0.CO;2

Denno, R.F., Mitter, M.S., Langellotto, G.A., Gratton, C., Finke, D.L., 2004. Interactions between a hunting spider and a web-builder: consequences of intraguild predation and cannibalism for prey suppression. Ecological Entomology 29, 566-577. https://doi.org/10.1111/j.03076946.2004.00628.x

Dick, J.T.A., Gallagher, K., Avlijas, S., Clarke, H.C., Lewis, S.E., Leung, S., Minchin, D., Caffrey, J., Alexander, M.E., Maguire, C., Harrod, C., Reid, N., Haddaway, N.R., Farnsworth, K.D., Penk, M., Ricciardi, A., 2013. Ecological impacts of an invasive predator explained and predicted by comparative functional responses. Biol Invasions 15, 837-846. https://doi.org/10.1007/s10530-012-0332-8

Ding-Xu, L., Juan, T., Zuo-Rui, S., 2007. Functional response of the predator Scolothrips takahashii to hawthorn spider mite, Tetranychus viennensis: effectof age and temperature. Biocontrol 52, 41. https://doi.org/10.1007/s10526-006-9015-7

Dinis, A.M., Pereira, J.A., Benhadi-Marín, J., Santos, S. a. P., 2016. Feeding preferences and functional responses of Calathus granatensis and Pterostichus globosus (Coleoptera: Carabidae) on pupae of Bactrocera oleae (Diptera: Tephritidae). Bulletin of Entomological Research 106, 701-709. https://doi.org/10.1017/S0007485316000213 
Donnelly, B.E., Phillips, T.W., 2001. Functional Response of Xylocoris flavipes (Hemiptera: Anthocoridae) - Effects of Prey Species and Habitat. Environ Entomol 30, 617-624. https://doi.org/10.1603/0046-225X-30.3.617

Dor, A., Valle-Mora, J., Rodríguez-Rodríguez, S.E., Liedo, P., 2014. Predation of Anastrepha ludens (Diptera: Tephritidae) by Norops serranoi (Reptilia: Polychrotidae): Functional Response and Evasion Ability. Environ Entomol 43, 706-715. https://doi.org/10.1603/EN13281

Dumont, H.J., Ali, A.J., Sarma, S.S.S., Mertens, J., 1994. Predatory Filter-Feeding in Fairy Shrimps: Functional Response of Streptocephalus proboscideus (Crustacea: Anostraca) Fed Anuraeopsis fissa (Rotifera). Internationale Revue der gesamten Hydrobiologie und Hydrographie 79, 511519. https://doi.org/10.1002/iroh.19940790403

Eggleston, D., Lipcius, R., Hines, A., 1992. Density-dependent predation by blue crabs upon infaunal clam species with contrasting distribution and abundance patterns. Marine Ecology Progress Series 85, 55-68. https://doi.org/10.3354/meps085055

Eggleston, D.B., 1990a. Behavioural Mechanisms Underlying Variable Functional Responses of Blue Crabs, Callinectes sapidus Feeding on Juvenile Oysters, Crassostrea virginica. Journal of Animal Ecology 59, 615-630. https://doi.org/10.2307/4884

Eggleston, D.B., 1990b. Functional responses of blue crabs Callinectes sapidus Rathbun feeding on juvenile oysters Crassostrea virginica (Gmelin): effects of predator sex and size, and prey size. Journal of Experimental Marine Biology and Ecology 143, 73-90. https://doi.org/10.1016/00220981(90)90112-P

Eggleston, D.B., 1990c. Foraging Behavior of the Blue Crab, Callinectes sapidus, on Juvenile Oysters, Crassostrea virginica: Effects of Prey Density and Size. Bulletin of Marine Science 46, 62-82.

El-Basha, N.A., Salman, M.S., Osman, M.A., 2012. Functional Response of Orius albidipennis (Hemiptera: Anthocoridae) to the Two-Spotted Spider Mite Tetranychus urticae (Acari: Tetranychidae). Journal of Entomology 9, 248-256.

Elliott, J.M., 2003. A comparative study of the functional response of four species of carnivorous stoneflies. Freshwater Biology 48, 191-202. https://doi.org/10.1046/j.1365-2427.2003.00982.x

Englund, G., Harms, S., 2001. The functional response of a predatory plant preying on swarming zooplankton. Oikos 94, 175-181. https://doi.org/10.1034/j.1600-0706.2001.11199.x

Enkegaard, A., Brødsgaard, H.F., Hansen, D.L., 2001. Macrolophus caliginosus: Functional response to whiteflies and preference and switching capacity between whiteflies and spider mites. Entomologia Experimentalis et Applicata 101, 81-88. https://doi.org/10.1046/j.15707458.2001.00893.x

Enriquez-Garcia, C., Nandini, S., Sarma, S.S.S., 2013. Feeding behaviour of Acanthocyclops americanus (Marsh) (Copepoda: Cyclopoida),. Journal of Natural History 47, 853-862.

Everson, P., 1979. The functional response of Phytoseiulus persimilis (Acarina: Phytoseiidae) to various densities of Tetranychus urticae (Acarina: Tetranychidae). The Canadian Entomologist 111, 7-10. https://doi.org/10.4039/Ent1117-1

Fan, Y., Petitt, F.L., 1994. Functional response of Neoseiulus barkeri Hughes on two-spotted spider mite (Acari: Tetranychidae). Exp Appl Acarol 18, 613-621. https://doi.org/10.1007/BF00051724

Fantinou, A.A., Baxevani, A., Drizou, F., Labropoulos, P., Perdikis, D., Papadoulis, G., 2012. Consumption rate, functional response and preference of the predaceous mite Iphiseius degenerans to Tetranychus urticae and Eutetranychus orientalis. Exp Appl Acarol 58, 133-144. https://doi.org/10.1007/s10493-012-9557-6

Farahani, H.K., Goldansaz, S.H., 2013. Is host age an important factor in the bionomics of Apanteles myeloenta (Hymenoptera: Braconidae)? EJE 110, 277-283. https://doi.org/10.14411/eje.2013.041 
Farazmand, A., Fathipour, Y., Kamali, K., 2012. Functional response and mutual interference of Neoseiulus californicus and Typhlodromus bagdasarjani (Acari: Phytoseiidae) on Tetranychus urticae (Acari: Tetranychidae). International Journal of Acarology 38, 369-376. https://doi.org/10.1080/01647954.2012.655310

Farhadi, R., Allahyari, H., Juliano, S.A., 2010. Functional Response of Larval and Adult Stages of Hippodamia variegata (Coleoptera: Coccinellidae) to Different Densities of Aphis fabae (Hemiptera: Aphididae). Environ Entomol 39, 1586-1592. https://doi.org/10.1603/EN09285

Faria, L.D.B., Trinca, L.A., Godoy, W.A.C., 2004. Cannibalistic Behavior and Functional Response in Chrysomya albiceps (Diptera: Calliphoridae). Journal of Insect Behavior 17, 251-261. https://doi.org/10.1023/B:JOIR.0000028574.91062.18

Farrokhi, S., Ashouri, A., Shirazi, J., Allahyari, H., Huigens, M.E., 2010. A comparative study on the functional response of Wolbachia-infected and uninfected forms of the parasitoid wasp Trichogramma brassicae. J Insect Sci 10. https://doi.org/10.1673/031.010.14127

Ferla, N.J., Marchetti, M., Johann, L., Haetinger, C., 2011. Functional response of Phytoseiulus macropilis under different Tetranychus urticae (Acari: Phytoseiidae, Tetranychidae) population density in laboratory. Zoologia 28.

Fernando, M.H.J.P., Hassell, M.P., 1980. Predator-prey responses in an acarine system. Res Popul Ecol 22, 301-322. https://doi.org/10.1007/BF02530853

Finke, D.L., Denno, R.F., 2002. Intraguild Predation Diminished in Complex-Structured Vegetation: Implications for Prey Suppression. Ecology 83, 643-652. https://doi.org/10.1890/00129658(2002)083[0643:IPDICS]2.0.CO;2

Fitzsimons, J., Williston, B., Williston, G., Bravener, G., Jonas, J.L., Claramunt, R.M., Marsden, J.E., Ellrott, B.J., 2006. Laboratory Estimates of Salmonine Egg Predation by Round Gobies (Neogobius melanostomus), Sculpins (Cottus cognatus and C. bairdi), and Crayfish (Orconectes propinquus). Journal of Great Lakes Research 32, 227-241. https://doi.org/10.3394/03801330(2006)32[227:LEOSEP]2.0.CO;2

Flinn, P.W., 1991. Temperature-Dependent Functional Response of the Parasitoid Cephalonomia waterstoni (Gahan) (Hymenoptera: Bethylidae) Attacking Rusty Grain Beetle Larvae (Coleoptera: Cucujidae). Environ Entomol 20, 872-876. https://doi.org/10.1093/ee/20.3.872

Foglar, H., Malausa, J.C., Wajnberg, E., 1990. The functional response and preference of Macrolophus caliginosus [Heteroptera: Miridae] for two of its prey: Myzus persicae and Tetranychus urticae. Entomophaga 35, 465-474. https://doi.org/10.1007/BF02375272

Folsom, T.C., Collins, N.C., 1984. The Diet and Foraging Behavior of the Larval Dragonfly Anax junius (Aeshnidae), with an Assessment of the Role of Refuges and Prey Activity. Oikos 42, 105-113. https://doi.org/10.2307/3544615

Fox, L.R., Murdoch, W.W., 1978. Effects of Feeding History on Short-Term and Long-Term Functional Responses in Notonecta hoffmanni. Journal of Animal Ecology 47, 945-959. https://doi.org/10.2307/3680

Frangópulos, M., Spyrakos, E., Guisande, C., 2011. Ingestion and clearance rates of the red Noctiluca scintillans fed on the toxic dinoflagellate Alexandrium minutum (Halim). Harmful Algae 10, 304309. https://doi.org/10.1016/j.hal.2010.11.002

Frewin, A.J., Xue, Y., Welsman, J.A., Broadbent, B.A., Schaafsma, A.W., Hallett, R.H., 2010. Development and Parasitism by Aphelinus certus (Hymenoptera: Aphelinidae), a Parasitoid of Aphis glycines (Hemiptera: Aphididae). Environ Entomol 39, 1570-1578. https://doi.org/10.1603/EN09312

Fritz, H., Durant, D., Guillemain, M., 2001. Shape and sources of variations of the functional response of wildfowl: an experiment with mallards, Anas platyrhynchos. Oikos 93, 488-496. https://doi.org/10.1034/j.1600-0706.2001.930314.x 
Frost, B.W., 1972. Effects of Size and Concentration of Food Particles on the Feeding Behavior of the Marine Planktonic Copepod Calanus pacificus. Limnology and Oceanography 17, 805-815. https://doi.org/10.4319/lo.1972.17.6.0805

Galarowicz, T.L., Wahl, D.H., 2005. Foraging by a young-of-the-year piscivore: the role of predator size, prey type, and density. Can. J. Fish. Aquat. Sci. 62, 2330-2342. https://doi.org/10.1139/f05-148

Garrido, S., Cruz, J., Santos, A.M.P., Ré, P., Saiz, E., 2013. Effects of temperature, food type and food concentration on the grazing of the calanoid copepod Centropages chierchiae. Journal of Plankton Research 35, 843-854. https://doi.org/10.1093/plankt/fbt037

Geange, S.W., Stier, A.C., 2010. Charismatic microfauna alter cyanobacterial production through a trophic cascade. Coral Reefs 29, 393-397. https://doi.org/10.1007/s00338-010-0606-5

Gergs, A., Hoeltzenbein, N.I., Ratte, H.T., 2010. Diurnal and nocturnal functional response of juvenile Notonecta maculata considered as a consequence of shifting predation behaviour. Behavioural Processes 85, 151-156. https://doi.org/10.1016/j.beproc.2010.07.006

Gergs, A., Ratte, H.T., 2009. Predicting functional response and size selectivity of juvenile Notonecta maculata foraging on Daphnia magna. Ecological Modelling 220, 3331-3341. https://doi.org/10.1016/j.ecolmodel.2009.08.012

Gibson, R.N., Ezzi, I.A., 1992. The relative profitability of particulate- and filter-feeding in the herring, Clupea harengus L. Journal of Fish Biology 40, 577-590. https://doi.org/10.1111/j.10958649.1992.tb02607.x

Gilbert, B., Tunney, T.D., McCann, K.S., DeLong, J.P., Vasseur, D.A., Savage, V., Shurin, J.B., Dell, A.I., Barton, B.T., Harley, C.D.G., Kharouba, H.M., Kratina, P., Blanchard, J.L., Clements, C., Winder, M., Greig, H.S., O'Connor, M.I., 2014. A bioenergetic framework for the temperature dependence of trophic interactions. Ecology Letters 17, 902-914. https://doi.org/10.1111/ele.12307

Gilg, O., Sittler, B., Sabard, B., Hurstel, A., Sané, R., Delattre, P., Hanski, I., 2006. Functional and numerical responses of four lemming predators in high arctic Greenland. Oikos 113, 193-216. https://doi.org/10.1111/j.2006.0030-1299.14125.x

Gilioli, G., Baumgärtner, J., Vacante, V., 2005. Temperature Influences on Functional Response of Coenosia attenuata (Diptera: Muscidae) Individuals. Journal of Economic Entomology 98, 15241530. https://doi.org/10.1603/0022-0493-98.5.1524

Gismervik, I., 2005. Numerical and functional responses of choreo- and oligotrich planktonic ciliates. Aquatic Microbial Ecology 40, 163-173. https://doi.org/10.3354/ame040163

Gitonga, L.M., Overholt, W.A., Löhr, B., Magambo, J.K., Mueke, J.M., 2002. Functional response of Orius albidipennis (Hemiptera: Anthocoridae) to Megalurothrips sjostedti (Thysanoptera: Thripidae). Biological Control 24, 1-6. https://doi.org/10.1016/S1049-9644(02)00001-4

Gonçalves, V., Gherardi, F., Rebelo, R., 2016. Modelling the predation effects of invasive crayfish, Procambarus clarkii (Girard, 1852), on invasive zebra mussel, Dreissena polymorpha (Pallas, 1771), under laboratory conditions. Italian Journal of Zoology 83, 59-67. https://doi.org/10.1080/11250003.2016.1138558

Gotoh, T., Nozawa, M., Yamaguchi, K., 2004. Prey consumption and functional response of three acarophagous species to eggs of the two-spotted spider mite in the laboratory. Applied Entomology and Zoology 39, 97-105. https://doi.org/10.1303/aez.2004.97

Greene, C.H., Landry, M.R., Monger, B.C., 1986. Foraging Behavior and Prey Selection by the Ambush Entangling Predator Pleurobrachia bachei. Ecology 67, 1493-1501. https://doi.org/10.2307/1939080

Gresens, S.E., Cothran, M.L., Thorp, J.H., 1982. The influence of temperature on the functional response of the dragonfly Celithemis fasciata (Odonata: Libellulidae). Oecologia 53, 281-284. https://doi.org/10.1007/BF00388999 
Griffen, B.D., Delaney, D.G., 2007. Species Invasion Shifts the Importance of Predator Dependence. Ecology 88, 3012-3021. https://doi.org/10.1890/07-0172.1

Gulbrandsen, J., 1991. Functional response of Atlantic halibut larvae related to prey density and distribution. Aquaculture 94, 89-98. https://doi.org/10.1016/0044-8486(91)90131-P

Gupta, R.K., Pervez, A., Guroo, M.A., Srivastava, K., 2012. Stage-specific functional response of an aphidophagous ladybird, Coccinella septempunctata (Coleoptera: Coccinellidae), to two aphid species. International Journal of Tropical Insect Science 32, 136-141. https://doi.org/10.1017/S1742758412000227

Gustafsson, P., Bergman, E., Greenberg, L.A., 2010. Functional response and size-dependent foraging on aquatic and terrestrial prey by brown trout (Salmo trutta L.). Ecology of Freshwater Fish 19, 170-177. https://doi.org/10.1111/j.1600-0633.2009.00401.x

Hada, A., Uye, S., 1991. Cannibalistic feeding behavior of the brackish-water copepod Sinocalanus tenellus. J Plankton Res 13, 155-166. https://doi.org/10.1093/plankt/13.1.155

Haddaway, N.R., Wilcox, R.H., Heptonstall, R.E.A., Griffiths, H.M., Mortimer, R.J.G., Christmas, M., Dunn, A.M., 2012. Predatory Functional Response and Prey Choice Identify Predation Differences between Native/Invasive and Parasitised/Unparasitised Crayfish. PLOS ONE 7, e32229. https://doi.org/10.1371/journal.pone.0032229

Hammill, E., Petchey, O.L., Anholt, B.R., 2010. Predator Functional Response Changed by Induced Defenses in Prey. The American Naturalist 176, 723-731. https://doi.org/10.1086/657040

Hansen, B., Tande, K.S., Berggreen, U.C., 1990. On the trophic fate of Phaeocystis pouchetii (Harlot). III. Functional responses in grazing demonstrated on juvenile stages of Calanus finmarchicus (Copepoda) fed diatoms and Phaeocystis. J Plankton Res 12, 1173-1187. https://doi.org/10.1093/plankt/12.6.1173

Hansen, P.J., 1992. Prey size selection, feeding rates and growth dynamics of heterotrophic dinoflagellates with special emphasis on Gyrodinium spirale. Marine Biology 114, 327-334. https://doi.org/10.1007/BF00349535

Hansen, P.J., Nielsen, T.G., 1997. Mixotrophic feeding of Fragilidium subglobosum (Dinophyceae) on three species of Ceratium: effects of prey concentration, prey species and light intensity. Marine Ecology Progress Series 147, 187-196. https://doi.org/10.3354/meps147187

Harborne, A.R., 2012. Seasonal variation in the functional response of a coral-reef piscivore alters the inverse density-dependent mortality of its prey. Coral Reefs 31, 247-251. https://doi.org/10.1007/s00338-011-0840-5

Hardman, J.M., Rogers, M.L., 1991. Effects of Temperature and Prey Density on Survival, Development, and Feeding Rates of Immature Typhlodromus pyri (Acari: Phytoseiidae). Environ Entomol 20, 1089-1096. https://doi.org/10.1093/ee/20.4.1089

Hardman, J.M., Turnbull, A.L., 1980. Functional response of the wolf spider, Pardosa vancouveri, to changes in the density of vestigial-winged fruit flies. Res Popul Ecol 21, 233-259. https://doi.org/10.1007/BF02513624

Hardman, J.M., Turnbull, A.L., 1974. The Interaction of Spatial Heterogeneity, Predator Competition and the Functional Response to Prey Density in a Laboratory System of Wolf Spiders (Araneae: Lycosidae) and Fruit Flies (Diptera: Drosophilidae). Journal of Animal Ecology 43, 155-171. https://doi.org/10.2307/3164

Hassanpour, M., Mohaghegh, J., Iranipour, S., Nouri-Ganbalani, G., Enkegaard, A., 2011. Functional response of Chrysoperla carnea (Neuroptera: Chrysopidae) to Helicoverpa armigera (Lepidoptera: Noctuidae): Effect of prey and predator stages. Insect Science 18, 217-224. https://doi.org/10.1111/j.1744-7917.2010.01360.x

Hassell, M.P., 1971. Mutual Interference between Searching Insect Parasites. Journal of Animal Ecology 40, 473-486. https://doi.org/10.2307/3256 
Hassell, M.P., Lawton, J.H., Beddington, J.R., 1977. Sigmoid Functional Responses by Invertebrate Predators and Parasitoids. Journal of Animal Ecology 46, 249-262. https://doi.org/10.2307/3959

Hauzy, C., Tully, T., Spataro, T., Paul, G., Arditi, R., 2010. Spatial heterogeneity and functional response: an experiment in microcosms with varying obstacle densities. Oecologia 163, 625-636. https://doi.org/10.1007/s00442-010-1585-5

He, Y., Zhao, J., Zheng, Y., Desneux, N., Wu, K., 2012. Lethal effect of imidacloprid on the coccinellid predator Serangium japonicum and sublethal effects on predator voracity and on functional response to the whitefly Bemisia tabaci. Ecotoxicology 21, 1291-1300. https://doi.org/10.1007/s10646-012-0883-6

Hedgespeth, M.L., Nilsson, P.A., Berglund, O., 2014. Ecological implications of altered fish foraging after exposure to an antidepressant pharmaceutical. Aquatic Toxicology, Antidepressants in the Aquatic Environment 151, 84-87. https://doi.org/10.1016/j.aquatox.2013.12.011

Heidarian, M., Fathipour, Y., Kamali, K., 2012. Functional response, switching, and prey-stage preference of Scolothrips longicornis (Thysanoptera: Thripidae) on Schizotetranychus smirnovi (Acari: Tetranychidae). Journal of Asia-Pacific Entomology.

Heimpel, G.E., Hough-Goldstein, J.A., 1994. Components of the Functional Response of Perillus bioculatus (Hemiptera: Pentatomidae). Environ Entomol 23, 855-859. https://doi.org/10.1093/ee/23.4.855

Helenius, L.K., Saiz, E., 2017. Feeding behaviour of the nauplii of the marine calanoid copepod Paracartia grani Sars: Functional response, prey size spectrum, and effects of the presence of alternative prey. PLOS ONE 12, e0172902. https://doi.org/10.1371/journal.pone.0172902

Heong, K.L., Bleih, S., Rubia, E.G., 1991. Prey preference of the wolf spider, Pardosa pseudoannulata (Boesenberg et Strand). Res Popul Ecol 33, 179-186. https://doi.org/10.1007/BF02513547

Hewett, S.W., 1980. The Effect of Prey Size on the Functional and Numerical Responses of a Protozoan Predator to Its Prey. Ecology 61, 1075-1081. https://doi.org/10.2307/1936826

Hildrew, A.G., Townsend, C.R., 1977. The influence of substrate on the functional response of Plectrocnemia conspersa (Curtis) larvae (Trichoptera: Polycentropodidae). Oecologia 31, 21-26. https://doi.org/10.1007/BF00348705

Hjelm, J., Johansson, F., 2003. Temporal variation in feeding morphology and size-structured population dynamics in fishes. Proc Biol Sci 270, 1407-1412. https://doi.org/10.1098/rspb.2003.2376

Hohberg, K., Traunspurger, W., 2005. Predator-prey interaction in soil food web: functional response, size-dependent foraging efficiency, and the influence of soil texture. Biol Fertil Soils 41, 419427. https://doi.org/10.1007/s00374-005-0852-9

Holling, C.S., 1965. The Functional Response of Predators to Prey Density and its Role in Mimicry and Population Regulation. The Memoirs of the Entomological Society of Canada 97, 5-60. https://doi.org/10.4039/entm9745fv

Holling, C.S., 1959a. The Components of Predation as Revealed by a Study of Small-Mammal Predation of the European Pine Sawfly1. The Canadian Entomologist 91, 293-320. https://doi.org/10.4039/Ent91293-5

Holling, C.S., 1959b. The Components of Predation as Revealed by a Study of Small-Mammal Predation of the European Pine Sawfly. The Canadian Entomologist 91, 293-320. https://doi.org/10.4039/Ent91293-5

Hooff, R.C., Bollens, S.M., 2004. Functional response and potential predatory impact of Tortanus dextrilobatus, a carnivorous copepod recently introduced to the San Francisco Estuary. Marine Ecology Progress Series 277, 167-179. https://doi.org/10.3354/meps277167

Hoque, M.F., Islam, M.W., Khalequzzaman, M., 2010. Functional response of Phytoseiulus persimilis Athias-Henriot to Tetranychus urticae Koch: effects of prey life stages and temperature. 
University Journal of Zoology, Rajshahi University 29, 1-8.

https://doi.org/10.3329/ujzru.v29i1.9458

Hossie, T.J., Murray, D.L., 2010. You can't run but you can hide: refuge use in frog tadpoles elicits density-dependent predation by dragonfly larvae. Oecologia 163, 395-404. https://doi.org/10.1007/s00442-010-1568-6

Houde, E.D., Schekter, R.C., 1980. Feeding by marine fish larvae: developmental and functional responses. Environ Biol Fish 5, 315-334. https://doi.org/10.1007/BF00005186

Houde, S.E.L., Roman, M.R., 1987. Effects of food quality on the functional ingestion response of the copepod Acartia tonsa. Marine Ecology Progress Series 40, 69-77.

Hunt, R.J., Swift, M., 2010. Predation by Larval Damselflies on Cladocerans. Journal of Freshwater Ecology 25, 345-351. https://doi.org/10.1080/02705060.2010.9664377

Hyatt, K.D., 1980. Mechanisms of food resource partitioning and the foraging strategies of rainbow trout (Salmo gairdneri) and kokanee (Oncorhynchus nerka) in Marion Lake, British Columbia. University of British Columbia. https://doi.org/10.14288/1.0095431

Iribarne, O., Armstrong, D., Fernández, M., 1995. Environmental impact of intertidal juvenile dungeness crab habitat enhancement: effects on bivalves and crab foraging rate. Journal of Experimental Marine Biology and Ecology 192, 173-194. https://doi.org/10.1016/0022-0981(95)00060-5

Isari, S., Saiz, E., 2011. Feeding performance of the copepod Clausocalanus lividus (Frost and Fleminger, 1968). J Plankton Res 33, 715-728. https://doi.org/10.1093/plankt/fbq149

Isenhour, D.J., Yeargan, K.V., 1981. Predation by Orius insidiosus on the Soybean Thrips, Sericothrips variabilis: Effect of Prey Stage and Density. Environ Entomol 10, 496-500. https://doi.org/10.1093/ee/10.4.496

Işikber, A.A., 2005. Functional Response of Two Coccinellid Predators, Scymnus levaillanti and Cycloneda sanguinea, to the Cotton Aphid, Aphis gossypii. Turk J Agric For 29, 347-355.

lyer, N., Rao, T., 1996. Responses of the predatory rotifer Asplanchna intermedia to prey species differing in vulnerability: laboratory and field studies. Freshwater Biology 36, 521-533. https://doi.org/10.1046/j.1365-2427.1996.d01-510.x

Jacobson, D.M., Anderson, D.M., 1993. Growth and grazing rates of Protoperidinium hirobis Abè, a thecate heterotrophic dinoflagellate. J Plankton Res 15, 723-736. https://doi.org/10.1093/plankt/15.7.723

Jafari, S., Fathipour, Y., Faraji, F., 2012. The influence of temperature on the functional response and prey consumption of Neoseiulus barkeri (Acari: Phytoseiidae) on Tetranychus urticae (Acari: Tetranychidae). Journal of Entomological Society of Iran 31, 39-52.

Jakobsen, H., Hansen, P., 1997. Prey size selection, grazing and growth response of the small heterotrophic dinoflagellate Gymnodinium sp. and the ciliate Balanion comatum--a comparative study. Marine Ecology Progress Series 158, 75-86. https://doi.org/10.3354/meps158075

Jaspers, C., Titelman, J., Hansson, L.J., Haraldsson, M., Ditlefsen, C.R., 2011. The invasive ctenophore Mnemiopsis leidyi poses no direct threat to Baltic cod eggs and larva. Limnology and Oceanography 56, 431-439. https://doi.org/10.4319/lo.2011.56.2.0431

Jeong, H.J., Ha, J.H., Yoo, Y.D., Park, J.Y., Kim, J.H., Kang, N.S., Kim, T.H., Kim, H.S., Yih, W.H., 2007a. Feeding by the Pfiesteria-like heterotrophic dinoflagellate Luciella masanensis. J. Eukaryot. Microbiol. 54, 231-241. https://doi.org/10.1111/j.1550-7408.2007.00259.x

Jeong, Hae Jin, Kang, H., Shim, J.H., Park, J.K., Kim, J.S., Song, J.Y., Choi, H.-J., 2001. Interactions among the toxic dinoflagellate Amphidinium carterae, the heterotrophic dinoflagellate Oxyrrhis marina, and the calanoid copepods Acartia spp. Marine Ecology Progress Series 218, 77-86.

Jeong, H.J., Kang, H.C., You, J.H., Jang, S.H., 2018a. Interactions between the Newly Described Small- and Fast-Swimming Mixotrophic Dinoflagellate Yihiella yeosuensis and Common Heterotrophic Protists. J. Eukaryot. Microbiol. 65, 612-626. https://doi.org/10.1111/jeu.12506 
Jeong, H.J., Kim, J.S., Song, J.Y., Kim, J.H., Kim, T.H., Kim, S.K., Kang, N.S., 2007b. Feeding by protists and copepods on the heterotrophic dinoflagellates Pfiesteria piscicida, Stoeckeria algicida, and Luciella masanensis. Marine Ecology Progress Series 349, 199-211. https://doi.org/10.3354/meps07094

Jeong, H. J., Kim, S.K., Kim, J.S., Kim, S.T., Yoo, Y.D., Yoon, J.Y., 2001. Growth and grazing rates of the heterotrophic dinoflagellate Polykrikos kofoidii on red-tide and toxic dinoflagellates. J. Eukaryot. Microbiol. 48, 298-308.

Jeong, H.J., Latz, M.I., 1994. Growth and grazing rates of the heterotrophic dinoflagellates Protoperidinium spp. on red tide dinoflagellates. Marine Ecology Progress Series 106, 173-185.

Jeong, H.J., Lee, K.H., Yoo, Y.D., Kang, N.S., Lee, K., 2011. Feeding by the Newly Described, NematocystBearing Heterotrophic Dinoflagellate Gyrodiniellum shiwhaense. Journal of Eukaryotic Microbiology 58, 511-524. https://doi.org/10.1111/j.1550-7408.2011.00580.x

Jeong, H.J., Shim, J.H., Lee, C.W., Kim, J.S., Koh, S.M., 1999. Growth and Grazing Rates of the Marine Planktonic Ciliate Strombidinopsis sp. on Red-Tide and Toxic Dinoflagellates. Journal of Eukaryotic Microbiology 46, 69-76. https://doi.org/10.1111/j.1550-7408.1999.tb04586.x

Jeong, H.J., Song, J.E., Kang, N.S., Kim, S., Yoo, Y.D., Park, J.Y., 2007c. Feeding by heterotrophic dinoflagellates on the common marine heterotrophic nanoflagellate Cafeteria sp. Marine Ecology Progress Series 333, 151-160. https://doi.org/10.3354/meps333151

Jeong, H.J., Yoo, Y.D., Kim, J.S., Kang, N.S., Kim, T.H., Kim, J.H., 2004. Feeding by the marine planktonic ciliate Strombidinopsis jeokjo on common heterotrophic dinoflagellates. Aquatic Microbial Ecology 36, 181-187. https://doi.org/10.3354/ame036181

Jeong, H.J., Yoon, J.Y., Kim, J.S., Yoo, Y.D., Seong, K.A., 2002. Growth and grazing rates of the prostomatid ciliate Tiarina fusus on red-tide and toxic algae. Aquatic Microbial Ecology 28, 289297. https://doi.org/10.3354/ame028289

Jeong, H.J., You, J.H., Lee, K.H., Kim, S.J., Lee, S.Y., 2018b. Feeding by common heterotrophic protists on the mixotrophic alga Gymnodinium smaydae (Dinophyceae), one of the fastest growing dinoflagellates. Journal of Phycology 54, 734-743. https://doi.org/10.1111/jpy.12775

Jeschke, J.M., Tollrian, R., 2005. Effects of predator confusion on functional responses. Oikos 111, 547555. https://doi.org/10.1111/j.1600-0706.2005.14118.x

Johansson, F., Leonardsson, K., 1998. Swimming speeds and activity levels of consumers at various resource and consumer densities under predation risk. Can. J. Zool. 76, 76-82. https://doi.org/10.1139/z97-165

Johansson, L., 1987. Experimental evidence for interactive habitat segregation between roach (Rutilus rutilus) and rudd (Scardinius erythrophthalmus) in a shallow eutrophic lake. Oecologia 73, 2127. https://doi.org/10.1007/BF00376972

John, E.H., Davidson, K., 2001. Prey selectivity and the influence of prey carbon:nitrogen ratio on microflagellate grazing. J. Exp. Mar. Biol. Ecol. 260, 93-111.

Johnson, D.W., 2006. Predation, Habitat Complexity, and Variation in Density-Dependent Mortality of Temperate Reef Fishes. Ecology 87, 1179-1188. https://doi.org/10.1890/00129658(2006)87[1179:PHCAVI]2.0.CO;2

Jones, D.B., Giles, K.L., Elliott, N.C., Payton, M.E., 2007. Parasitism of Greenbug, <1>Schizaphis graminum $</ \mid>$, by the Parasitoid $<\mid>$ Lysiphlebus testaceipes $</ \mid>$ at Winter Temperatures. Environmental Entomology 36, 1-8. https://doi.org/10.1603/0046225X(2007)36[1:POGSGB]2.0.CO;2

Kalinoski, R.M., DeLong, J.P., 2016. Beyond body mass: how prey traits improve predictions of functional response parameters. Oecologia 180, 543-550. https://doi.org/10.1007/s00442-015-3487-z

Kalsi, M., Seal, D.R., Nuessly, G.S., Capinera, J.L., Martin, C.G., 2014. Distribution of Zelus longipes (Hemiptera: Reduviidae) in South Florida Corn Fields and Its Functional Response to Corn- 
Infesting Picture-Winged Flies (Diptera: Ulidiidae). Environ Entomol 43, 1223-1234.

https://doi.org/10.1603/EN13271

Kamiyama, T., 1997. Growth and grazing responses of tintinnid ciliates feeding on the toxic dinoflagellate Heterocapsa circularisquama. Marine Biology 128, 509-515. https://doi.org/10.1007/s002270050117

Kamiyama, T., Tsujino, M., Matsuyama, Y., Uchida, T., 2005. Growth and grazing rates of the tintinnid ciliate Favella taraikaensis on the toxic dinoflagellate Alexandrium tamarense. Marine Biology 147, 989-997. https://doi.org/10.1007/s00227-005-1629-2

Kasap, I., Atlihan, R., 2011. Consumption rate and functional response of the predaceous mite Kampimodromus aberrans to two-spotted spider mite Tetranychus urticae in the laboratory. Exp Appl Acarol 53, 253-261. https://doi.org/10.1007/s10493-010-9400-x

Katz, C.H., 1985. A Nonequilibrium Marine Predator-Prey Interaction. Ecology 66, 1426-1438. https://doi.org/10.2307/1938005

Khan, A.A., 2013. Evaluation of the biological control efficiency of four spiders using functional response experiments. The Bioscan 8, 1123-1128.

Khan, A.A., 2012. Functional response of Pardosa altitudis Tikader and Malhotra, Teragnatha maxillosa Thorell, Neoscona mukherjei Tikader and heridion sp. to rice grasshopper Oxya nitidula (Wlk.). Oryza 49, 39-44.

Khan, A.A., 2009. Functional response of Adalia tetraspilota (Hope) (Coleoptera: Coccinellidae) on cabbage aphid, Brevicoryne brassicae (L.). Journal of Biological Control 23, 246-248.

Khan, A.A., Shah, M.A., Majid, S., 2016. Functional Response of Four Syrphid Predators Associated With Green Apple Aphid (Hemiptera: Aphididae) in Laboratory. J Econ Entomol 109, 78-83. https://doi.org/10.1093/jee/tov264

Kharboutli, M.S., Mack, T.P., 1993. Effect of Temperature, Humidity, and Prey Density on Feeding Rate of the Striped Earwig (Dermaptera: Labiduridae). Environ Entomol 22, 1134-1139. https://doi.org/10.1093/ee/22.5.1134

Kim, J.S., Jeong, H.J., 2004. Feeding by the heterotrophic dinoflagellates Gyrodinium dominans and G. spirale on the red-tide dinoflagellate Prorocentrum minimum. Marine Ecology Progress Series 280, 85-94. https://doi.org/10.3354/meps280085

Kimmance, S.A., Atkinson, D., Montagnes, D.J.S., 2006. Do temperature-food interactions matter? Responses of production and its components in the model heterotrophic flagellate Oxyrrhis marina. Aquatic Microbial Ecology 42, 63-73. https://doi.org/10.3354/ame042063

Koch, R.L., Hutchison, W.D., Venette, R.C., Heimpel, G.E., 2003. Susceptibility of immature monarch butterfly, Danaus plexippus (Lepidoptera: Nymphalidae: Danainae), to predation by Harmonia axyridis (Coleoptera: Coccinellidae). Biological Control 28, 265-270. https://doi.org/10.1016/S1049-9644(03)00102-6

Kopp, M., Tollrian, R., 2003. Trophic size polyphenism in lembadion bullinum: costs and benefits of an inducible offense. Ecology 84, 641-651. https://doi.org/10.1890/00129658(2003)084[0641:TSPILB]2.0.CO;2

Korpimaki, E., Norrdahl, K., 1991. Numerical and Functional Responses of Kestrels, Short-Eared Owls, and Long-Eared Owls to Vole Densities. Ecology 72, 814-826. https://doi.org/10.2307/1940584

Korstad, J., Vadstein, O., Olsen, Y., 1989. Feeding kinetics of Brachionus plicatilis fed Isochrysis galbana. Hydrobiologia 186, 51-57. https://doi.org/10.1007/BF00048896

Koski, M.L., Johnson, B.M., 2002. Functional response of kokanee salmon (Oncorhynchus nerka) to Daphnia at different light levels. Can. J. Fish. Aquat. Sci. 59, 707-716. https://doi.org/10.1139/f02-045 
Koveos, D.S., Broufas, G.D., 2000. Functional response of Euseius finlandicus and <i>Amblyseius andersoni to Panonychus ulmi on apple and peach leaves in the laboratory. Exp Appl Acarol 24, 247-256. https://doi.org/10.1023/A:1006431710313

Kratina, P., Vos, M., Anholt, B.R., 2007. Species Diversity Modulates Predation. Ecology 88, 1917-1923. https://doi.org/10.1890/06-1507.1

Kremer, P., Reeve, M.R., Syms, M.A., 1986. The nutritional ecology of the ctenophore Bolinopsis vitrea: comparisons with Mnemiopsis mccradyi from the same region. J Plankton Res 8, 1197-1208. https://doi.org/10.1093/plankt/8.6.1197

Krishnaraj, R., Pritchard, G., 1995. The influence of larval size, temperature, and components of the functional response to prey density on growth rates of the dragonflies Lestes disjunctus and Coenagrion resolutum (Insecta: Odonata). Can. J. Zool. 73, 1672-1680. https://doi.org/10.1139/z95-199

Kroetz, A.M., Powers, S.P., 2015. Eating between the lines: functional feeding response of bonnetheads (Sphyrna tiburo). Environ Biol Fish 98, 655-661. https://doi.org/10.1007/s10641-014-0302-3

Krylov, P.I., 1988. Predation of the freshwater cyclopoid copepod Megacyclops gigas on lake zooplankton: Functional response and prey selection. Archiv fuer Hydrobiologie 113, 231-250.

Kumar, B., Mishra, G., OMKAR, 2014. Functional response and predatory interactions in conspecific and heterospecific combinations of two congeneric species (Coleoptera: Coccinellidae). EJE 111, 257-265. https://doi.org/10.14411/eje.2014.025

Kumar, R., Rao, T.R., 2003. Predation on Mosquito Larvae by Mesocyclops thermocyclopoides (Copepoda: Cyclopoida) in the Presence of Alternate Prey. International Review of Hydrobiology 88, 570-581. https://doi.org/10.1002/iroh.200310631

Kushner, R.B., Hovel, K.A., 2006. Effects of native predators and eelgrass habitat structure on the introduced Asian mussel Musculista senhousia (Benson in Cantor) in southern California. Journal of Experimental Marine Biology and Ecology 332, 166-177. https://doi.org/10.1016/j.jembe.2005.11.011

Kustutan, O., Cakmak, I., 2009. Development, Fecundity, and Prey Consumption of Neoseiulus californicus (McGregor) Fed Tetranychus cinnabarinus Boisduval. Turkish Journal of Agriculture and Forestry 33, 19-28.

Lafontaine, Y. de, Leggett, W.C., 1988. Predation by Jellyfish on Larval Fish: An Experimental Evaluation Employing in situ Enclosures. Can. J. Fish. Aquat. Sci. 45, 1173-1190. https://doi.org/10.1139/f88-140

Lafontaine, Y.D., Leggett, W.C., 1987. Effect of Container Size on Estimates of Mortality and Predation Rates in Experiments with Macrozooplankton and Larval Fish. Can. J. Fish. Aquat. Sci. 44, 15341543. https://doi.org/10.1139/f87-185

Laing, J.E., Osborn, J.A.L., 1974. The effect of prey density on the functional and numerical reponses of three species of predatory mites. Entomophaga 19, 267-277. https://doi.org/10.1007/BF02371052

Lampert, W., 1994. Phenotypic plasticity of the filter screens in Daphnia : Adaptation to a low-food environment. Limnology and Oceanography 39, 997-1006. https://doi.org/10.4319/lo.1994.39.5.0997

Lampitt, R.S., 1978. Carnivorous feeding by a small marine copepod. Limnology and Oceanography 23, 1228-1231. https://doi.org/10.4319/lo.1978.23.6.1228

Laverty, C., Dick, J.T.A., Alexander, M.E., Lucy, F.E., 2015. Differential ecological impacts of invader and native predatory freshwater amphipods under environmental change are revealed by comparative functional responses. Biol Invasions 17, 1761-1770. https://doi.org/10.1007/s10530-014-0832-9 
Laybourn, J., 1976. Energy budgets for Stentor coeruleus Ehrenberg (Ciliophora). Oecologia 22, 431-437. https://doi.org/10.1007/BF00345319

LeCato, G.L., 1978. Functional Response of Red Flour Beetles to Density of Cigarette Beetles and the Role of Predation in Population Regulations. Environ Entomol 7, 77-80. https://doi.org/10.1093/ee/7.1.77

LeCato, G.L., Arbogast, R.T., 1979. Functional Response of Xylocoris flavipes to Angoumois Grain Moth and Influence of Predation on Regulation of Laboratory Populations. J Econ Entomol 72, 847849. https://doi.org/10.1093/jee/72.6.847

Lee, J.-H., Kang, T.-J., 2004. Functional response of Harmonia axyridis (Pallas) (Coleoptera: Coccinellidae) to Aphis gossypii Glover (Homoptera: Aphididae) in the Laboratory. Biological Control 31, 306310. https://doi.org/10.1016/j.biocontrol.2004.04.011

Letcher, B.H., Rice, J.A., Crowder, L.B., Binkowski, F.P., 1997. Size - and species-dependent variability in consumption and growth rates of larvae and juveniles of three freshwater fishes. Can. J. Fish. Aquat. Sci. 54, 405-414. https://doi.org/10.1139/f96-273

Lim, A.S., Jeong, H.J., Ok, J.H., Kim, S.J., 2018. Feeding by the harmful phototrophic dinoflagellate Takayama tasmanica (Family Kareniaceae). Harmful Algae 74, 19-29. https://doi.org/10.1016/j.hal.2018.03.009

Lin, S., Mulholland, M.R., Zhang, H., Feinstein, T.N., Jochem, F.J., Carpenter, E.J., 2004. Intense Grazing and Prey-Dependent Growth of Pfiesteria piscicida (dinophyceae). Journal of Phycology 40, 1062-1073. https://doi.org/10.1111/j.1529-8817.2004.03217.x

Líznarová, E., Pekár, S., 2013. Dangerous prey is associated with a type 4 functional response in spiders. Animal Behaviour 85, 1183-1190. https://doi.org/10.1016/j.anbehav.2013.03.004

Ljunggren, L., Sandström, A., 2007. Influence of visual conditions on foraging and growth of juvenile fishes with dissimilar sensory physiology. Journal of Fish Biology 70, 1319-1334. https://doi.org/10.1111/j.1095-8649.2007.01412.x

Long, W.C., Popp, J., Swiney, K.M., Van Sant, S.B., 2012. Cannibalism in red king crab, Paralithodes camtschaticus (Tilesius, 1815): Effects of habitat type and predator density on predator functional response. Journal of Experimental Marine Biology and Ecology 422-423, 101-106. https://doi.org/10.1016/j.jembe.2012.04.019

Long, W.C., Whitefleet-Smith, L., 2013. Cannibalism in red king crab: Habitat, ontogeny, and the predator functional response. Journal of Experimental Marine Biology and Ecology 449, 142148. https://doi.org/10.1016/j.jembe.2013.09.004

López-Urrutia, Á., Harris, R.P., Smith, T., 2004. Predation by calanoid copepods on the appendicularian Oikopleura dioica. Limnology and Oceanography 49, 303-307. https://doi.org/10.4319/lo.2004.49.1.0303

Losey, J.E., Denno, R.F., 1998. Positive Predator-Predator Interactions: Enhanced Predation Rates and Synergistic Suppression of Aphid Populations. Ecology 79, 2143-2152. https://doi.org/10.1890/0012-9658(1998)079[2143:PPPIEP]2.0.CO;2

Loughridge, A.H., Luff, M.L., 1983. Aphid Predation by Harpalus rufipes (Degeer) (Coleoptera: Carabidae) in the Laboratory and Field. Journal of Applied Ecology 20, 451-462. https://doi.org/10.2307/2403519

Lyon, S.R., Sjulin, C.A., Sullivan, K.M., DeLong, J.P., 2018. Condition-dependent foraging in the wolf spider Hogna baltimoriana. Food Webs 14, 5-8. https://doi.org/10.1016/j.fooweb.2017.12.003

MacNeil, C., Dick, J., Alexander, M., Dodd, J., Ricciardi, A., 2013. Predators vs. alien: differential biotic resistance to an invasive species by two resident predators. NeoBiota 19, 1-19. https://doi.org/10.3897/neobiota.19.4839 
Madadi, H., Enkegaard, A., Brodsgaard, H.F., Kharrazi-Pakdel, A., Mohaghegh, J., Ashouri, A., 2007. Host plant effects on the functional response of Neoseiulus cucumeris to onion thrips larvae. Journal of Applied Entomology 131, 728-733. https://doi.org/10.1111/j.1439-0418.2007.01206.x

Madadi, H., Mohajeri Parizi, E., Allahyari, H., Enkegaard, A., 2011. Assessment of the biological control capability of Hippodamia variegata (Col.: Coccinellidae) using functional response experiments. J Pest Sci 84, 447-455. https://doi.org/10.1007/s10340-011-0387-9

Mandour, N.S., El-Basha, N.A.-S., Liu, T.-X., 2006. Functional response of the ladybird, Cydonia vicina nilotica to cowpea aphid, Aphis craccivora in the laboratory. Insect Science 13, 49-54. https://doi.org/10.1111/j.1744-7917.2006.00067.x

Mansour, F., Heimbach, U., 1993. Evaluation of lycosid, micryphantid and linyphiid spiders as predators of Rhopalosiphum padi (Hom.: Aphididae) and their functional response to prey densitylaboratory experiments. Entomophaga 38, 79-87. https://doi.org/10.1007/BF02373142

Márquez, L., Caballos, M., Domingues, P., 2007a. Functional response of early stages of the cuttlefish Sepia officinalis preying on the mysid Mesopodopsis slabberi. Marine Biology Research 3, 462467. https://doi.org/10.1080/17451000701751479

Márquez, L., Quintana, D., Almansa, E., Navas, J.I., 2007b. Effects of visual conditions and prey density on feeding kinetics of paralarvae of Octopus vulgaris from a laboratory spawning. J Molluscan Stud 73, 117-121. https://doi.org/10.1093/mollus/eym003

Maselou, D., Perdikis, D., Fantinou, A., 2015. Effect of hunger level on prey consumption and functional response of the predator Macrolophus pygmaeus. Bulletin of Insectology 68, 211-218.

McCaffrey, J.P., Horsburgh, R.L., 1986. Functional Response of Orius insidiosus (Hemiptera: Anthocoridae) to the European Red Mite, Panonychus ulmi (Acari: Tetranychidae), at Different Constant Temperatures. Environ Entomol 15, 532-535. https://doi.org/10.1093/ee/15.3.532

McCann, K., Hastings, A., Huxel, G.R., 1998. Weak trophic interactions and the balance of nature. Nature 395, 794-798. https://doi.org/10.1038/27427

McCoull, C.J., Swain, R., Barnes, R.W., 1998. Effect of temperature on the functional response and components of attack rate in Naucoris congrex Stål (Hemiptera: Naucoridae). Australian Journal of Entomology 37, 323-327. https://doi.org/10.1111/j.1440-6055.1998.tb01591.x

McCoy, M.W., Bolker, B.M., Warkentin, K.M., Vonesh, J.R., 2011. Predicting Predation through Prey Ontogeny Using Size-Dependent Functional Response Models. The American Naturalist 177, 752-766. https://doi.org/10.1086/659950

McMahon, J.W., Rigler, F.H., 1965. Feeding Rate of Daphnia Magna Straus in Different Foods Labeled with Radioactive Phosphorus. Limnology and Oceanography 10, 105-113. https://doi.org/10.4319/lo.1965.10.1.0105

McQueen, D.J., 1969. Reduction of Zooplankton Standing Stocks by Predaceous Cyclops bicuspidatus thomasi in Marion Lake, British Columbia. J. Fish. Res. Bd. Can. 26, 1605-1618. https://doi.org/10.1139/f69-144

Messier, F., 1994. Ungulate Population Models with Predation: A Case Study with the North American Moose. Ecology 75, 478-488. https://doi.org/10.2307/1939551

Messina, F.J., Hanks, J.B., 1998. Host Plant Alters the Shape of the Functional Response of an Aphid Predator (Coleoptera: Coccinellidae). Environ Entomol 27, 1196-1202. https://doi.org/10.1093/ee/27.5.1196

Michalko, R., Pekár, S., 2017. The Behavioral Type of a Top Predator Drives the Short-Term Dynamic of Intraguild Predation. The American Naturalist 189, 242-253. https://doi.org/10.1086/690501

Midthassel, A., Leather, S.R., Wright, D.J., Baxter, I.H., 2014. The functional and numerical response of Typhlodromips swirskii (Acari: Phytoseiidae) to the factitious prey Suidasia medanensis (Acari: Suidasidae) in the context of a breeding sachet. Biocontrol Science and Technology 24, 361-374. https://doi.org/10.1080/09583157.2013.863270 
Miller, T.J., Crowder, L.B., Rice, J.A., Binkowski, F.P., 1992. Body Size and the Ontogeny of the Functional Response in Fishes. Can. J. Fish. Aquat. Sci. 49, 805-812. https://doi.org/10.1139/f92-091

Mills, N.J., Lacan, I., 2004. Ratio dependence in the functional response of insect parasitoids: evidence from Trichogramma minutum foraging for eggs in small host patches. Ecological Entomology 29, 208-216. https://doi.org/10.1111/j.0307-6946.2004.00584.x

Moayeri, H.R.S., Madadi, H., Pouraskari, H., Enkegaard, A., 2013. Temperature dependent functional response of Diaeretiella rapae (Hymenoptera: Aphidiidae) to the cabbage aphid, Brevicoryne brassicae (Hemiptera: Aphididae). EJE 110, 109-113. https://doi.org/10.14411/eje.2013.015

Mohaghegh, Clercq, D., Tirry, 2001. Functional response of the predators Podisus maculiventris (Say) and Podisus nigrispinus (Dallas) (Het., Pentatomidae) to the beet armyworm, Spodoptera exigua (Hübner) (Lep., Noctuidae): effect of temperature. Journal of Applied Entomology 125, 131-134. https://doi.org/10.1046/j.1439-0418.2001.00519.x

Moksnes, P.-O., Lipcius, R.N., Pihl, L., van Montfrans, J., 1997. Cannibal-prey dynamics in young juveniles and postlarvae of the blue crab. Journal of Experimental Marine Biology and Ecology 215, 157187. https://doi.org/10.1016/S0022-0981(97)00052-X

Mondal, R.P., Ghosh, A., Bandyopadhyay, S., Chandra, G., 2014. Functional response analysis of Anisops sardea (Hemiptera: Notonectidae) against Culex quinquefasciatus in laboratory condition. Indian J. Med. Res. 140, 551-555.

Monteleone, D.M., Duguay, L.E., 1988. Laboratory studies of predation by the ctenophore Mnemiopsis leidyi on the early stages in the life history of the bay anchovy, Anchoa mitchilli. J Plankton Res 10, 359-372. https://doi.org/10.1093/plankt/10.3.359

Montserrat, M., Albajes, R., Castañé, C., 2000. Functional Response of Four Heteropteran Predators Preying on Greenhouse Whitefly (Homoptera: Aleyrodidae) and Western Flower Thrips (Thysanoptera: Thripidae). Environ Entomol 29, 1075-1082. https://doi.org/10.1603/0046225X-29.5.1075

Monzó, C., Mollá, Ó., Castañera, P., Urbaneja, A., 2009. Activity-density of Pardosa cribata in Spanish citrus orchards and its predatory capacity on Ceratitis capitata and Myzus persicae. BioControl 54, 393-402. https://doi.org/10.1007/s10526-008-9199-0

Moore, M.V., 1988. Density-dependent predation of early instar $</ i>$ Chaoborus $<i>$ feeding on multispecies prey assemblages. Limnology and Oceanography 33, 256-268. https://doi.org/10.4319/lo.1988.33.2.0256

Morales, J., Burandt, C.L., 1985. Interactions Between Cycloneda sanguinea and the Brown Citrus Aphid: Adult Feeding and Larval Mortality. Environ Entomol 14, 520-522. https://doi.org/10.1093/ee/14.4.520

Morales-Ventura, J., Nandini, S., Sarma, S.S.S., 2004. Functional responses during the early larval stages of the charal fish Chirostoma riojai (Pisces: Atherinidae) fed rotifers and cladocerans. Journal of Applied Ichthyology 20, 417-421. https://doi.org/10.1111/j.1439-0426.2004.00565.x

Morand, P., Carré, C., Biggs, D.C., 1987. Feeding and metabolism of the jellyfish Pelagia noctiluca (scyphomedusae, semaeostomae). J Plankton Res 9, 651-665. https://doi.org/10.1093/plankt/9.4.651

Morozov, A., Arashkevich, E., Reigstad, M., Falk-Petersen, S., 2008. Influence of spatial heterogeneity on the type of zooplankton functional response: A study based on field observations. Deep Sea Research Part II: Topical Studies in Oceanography, Carbon flux and ecosystem feedback in the northern Barents Sea in an era of climate change 55, 2285-2291. https://doi.org/10.1016/j.dsr2.2008.05.008

Moss, J.H., Beauchamp, D.A., 2007. Functional response of juvenile pink and chum salmon: effects of consumer size and two types of zooplankton prey. Journal of Fish Biology 70, 610-622. https://doi.org/10.1111/j.1095-8649.2007.01340.x 
Moustahfid, H., Tyrrell, M.C., Link, J.S., Nye, J.A., Smith, B.E., Gamble, R.J., 2010. Functional feeding responses of piscivorous fishes from the northeast US continental shelf. Oecologia 163, 10591067. https://doi.org/10.1007/s00442-010-1596-2

Mrosso, F., Mwatawala, M., Rwegasira, G., 2013. Functional Responses of Cheilomenes propingua, $C$. lunata and C. sulphurea (Coleoptera: Coccinellidae) to Predation on Aphis gossypii (Homoptera: Aphididae) in Eastern Tanzania. Journal of Entomology 10, 76-85. https://doi.org/10.3923/je.2013.76.85

Müller, H., Schlegel, A., 1999. Responses of three freshwater planktonic ciliates with different feeding modes to cryptophyte and diatom prey. Aquatic Microbial Ecology 17, 49-60.

Munk, P., 1995. Foraging behaviour of larval cod (Gadus morhua) influenced by prey density and hunger. Marine Biology 122, 205-212. https://doi.org/10.1007/BF00348933

Munk, P., Kiøboe, T., 1985. Feeding behaviour and swimming activity of larval herring (Clupea harengus) in relation to density of copepod nauplii. Marine Ecology Progress Series 24, 15-21. https://doi.org/10.3354/meps024015

Munyaneza, J., Obrycki, J.J., 1997. Functional Response of Coleomegilla maculata (Coleoptera: Coccinellidae) to Colorado Potato Beetle Eggs (Coleoptera: Chrysomelidae). Biological Control 8, 215-224. https://doi.org/10.1006/bcon.1997.0509

Murdie, G., Hassell, M.P., 1973. Food distribution, searching success and predator-prey models. The mathematical theory of the dynamics of biological populations 87-101.

Murdoch, W.W., Avery, S., Smyth, M.E.B., 1975. Switching in Predatory Fish. Ecology 56, 1094-1105. https://doi.org/10.2307/1936149

Murray, G.P.D., Stillman, R.A., Britton, J.R., 2016. Habitat complexity and food item size modify the foraging behaviour of a freshwater fish. Hydrobiologia 766, 321-332. https://doi.org/10.1007/s10750-015-2465-0

Murray, G.P.D., Stillman, R.A., Gozlan, R.E., Britton, J.R., 2013. Experimental Predictions of The Functional Response of A Freshwater Fish. Ethology 119, 751-761. https://doi.org/10.1111/eth.12117

Muschiol, D., Markovic, M., Threis, I., Traunspurger, W., 2008a. Predatory copepods can control nematode populations: A functional-response experiment with Eucyclops subterraneus and bacterivorous nematodes. FUNDAMENTAL AND APPLIED LIMNOLOGY 172.

Muschiol, D., Traunspurger, W., Marković, M., Threis, I., 2008b. Predator-prey relationship between the cyclopoid copepod Diacyclops bicuspidatus and a free-living bacterivorous nematode. Nematology 10, 55-62. https://doi.org/10.1163/156854108783360203

Nachappa, P., Braman, S.K., Guillebeau, L.P., All, J.N., 2006. Functional Response of the Tiger Beetle Megacephala carolina carolina (Coleoptera: Carabidae) on Twolined Spittlebug (Hemiptera: Cercopidae) and Fall Armyworm (Lepidoptera: Noctuidae). Journal of Economic Entomology 99, 1583-1589. https://doi.org/10.1603/0022-0493-99.5.1583

Nagai, K., Yano, E., 2000. Predation by Orius sauteri (Poppius) (Heteroptera: Anthocoridae) on Thrips palmi Karny (Thysanoptera: Thripidae): Functional response and selective predation. Applied Entomology and Zoology 35, 565-574. https://doi.org/10.1303/aez.2000.565

Nandini, S., Sarma, S.S.S., 1999. Effect of starvation time on the prey capture behaviour, functional response and population growth of Asplanchna sieboldi (Rotifera). Freshwater Biology 42, 121130. https://doi.org/10.1046/j.1365-2427.1999.00467.x

Nejstgaard, J.C., Båmstedt, U., Bagøien, E., Solberg, P.T., 1995. Algal constraints on copepod grazing. Growth state, toxicity, cell size, and season as regulating factors. ICES J Mar Sci 52, 347-357. https://doi.org/10.1016/1054-3139(95)80050-6

Nielsen, Ó.K., 1999. Gyrfalcon predation on ptarmigan: numerical and functional responses. Journal of Animal Ecology 68, 1034-1050. https://doi.org/10.1046/j.1365-2656.1999.00351.x 
Nilsen, E.B., Linnell, J.D.C., Odden, J., Andersen, R., 2009. Climate, season, and social status modulate the functional response of an efficient stalking predator: the Eurasian lynx. J Anim Ecol 78, 741751. https://doi.org/10.1111/j.1365-2656.2009.01547.x

Nordlund, D.A., Morrison, R.K., 1990. Handling time, prey preference, and functional response for Chrysoperla rufilabris in the laboratory. Entomologia Experimentalis et Applicata 57, 237-242. https://doi.org/10.1111/j.1570-7458.1990.tb01435.x

Novak, M., Wootton, J.T., 2010. Using experimental indices to quantify the strength of species interactions. Oikos 119, 1057-1063. https://doi.org/10.1111/j.1600-0706.2009.18147.x

Novich, R.A., Erickson, E.K., Kalinoski, R.M., DeLong, J.P., 2014. The temperature independence of interaction strength in a sit-and-wait predator. Ecosphere 5, art137. https://doi.org/10.1890/ES14-00216.1

Nwilene, F.E., Nachman, G., 1996. Functional responses of Iphiseius degenerans and Neoseiulus teke (Acari: Phytoseiidae) to changes in the density of the cassava green mite, Mononychellus tanajoa (Acari: Tetranychidae). Exp Appl Acarol 20, 259-271. https://doi.org/10.1007/BF00052876

O'Brien, W.J., Barfield, M., Sigler, K., 2001. The functional response of drift-feeding Arctic grayling: the effects of prey density, water velocity, and location efficiency. Can. J. Fish. Aquat. Sci. 58, 19571963. https://doi.org/10.1139/f01-138

O’Donoghue, M., Boutin, S., Krebs, C.J., Zuleta, G., Murray, D.L., Hofer, E.J., 1998. Functional Responses of Coyotes and Lynx to the Snowshoe Hare Cycle. Ecology 79, 1193-1208. https://doi.org/10.2307/176736

Ofuya, T.I., Akingbohungbe, A.E., 1988. Functional and Numerical Responses of Cheilomenes lunata (Fabricius) (Coleoptera: Coccinellidae) Feeding on the Cowpea Aphid, Aphis craccivora Koch (Homoptera: Aphididae). International Journal of Tropical Insect Science 9, 543-546. https://doi.org/10.1017/S1742758400011127

Ohlberger, J., Mehner, T., Staaks, G., Hölker, F., 2008. Is ecological segregation in a pair of sympatric coregonines supported by divergent feeding efficiencies? Can. J. Fish. Aquat. Sci. 65, 2105-2113. https://doi.org/10.1139/F08-120

Olsen, E.M., Jørstad, T., Kaartvedt, S., 2000. The feeding strategies of two large marine copepods. J Plankton Res 22, 1513-1528. https://doi.org/10.1093/plankt/22.8.1513

Opit, G.P., Roitberg, B., Gillespie, D.R., 1997. The functional response and prey preference of Feltiella acarisuga (Vallot) (Diptera: Cecidomyiidae) for two of its prey: male and female twospotted spider mites, Tetranychus urticae koch (Acari: Tetranychiidae). The Canadian Entomologist 129, 221-227. https://doi.org/10.4039/Ent129221-2

Oyugi, D.O., Cucherousset, J., Baker, D.J., Britton, J.R., 2012. Effects of temperature on the foraging and growth rate of juvenile common carp, Cyprinus carpio. Journal of Thermal Biology 37, 89-94. https://doi.org/10.1016/j.jtherbio.2011.11.005

Palanichamy, S., 1983. Influence of spatial heterogeneity and prey density on predatory behaviour of the tropical spiders Cyrtophora cicatrosa (Stoliczka) and Marpissa calcutaensis (Tikader) (Araneae, Araneidae). Proc Ani Sci 92, 429-435. https://doi.org/10.1007/BF03186214

Papanikolaou, N.E., Martinou, A.F., Kontodimas, D.C., Matsinos, Y.G., Milonas, P.G., 2011. Functional responses of immature stages of Propylea quatuordecimpunctata (Coleoptera: Coccinellidae) to Aphis fabae (Hemiptera: Aphididae). European Journal of Entomology 108, 391-395. https://doi.org/10.14411/eje.2011.049

Parajulee, M.N., Phillips, T.W., Hogg, D.B., 1994. Functional Response of Lyctocoris campestris (F.) Adults: Effects of Predator Sex, Prey Species, and Experimental Habitat. Biological Control 4, 8087. https://doi.org/10.1006/bcon.1994.1014 
Parajulee, M.N., Shrestha, R.B., Leser, J.F., Wester, D.B., Blanco, C.A., 2006. Evaluation of the Functional Response of Selected Arthropod Predators on Bollworm Eggs in the Laboratory and Effect of Temperature on Their Predation Efficiency. Environ Entomol 35, 379-386. https://doi.org/10.1603/0046-225X-35.2.379

Paulsson, N., n.d. Shape and dynamical consequences of the functional response of Daphnia magna.

Pekár, S., 2005. Predatory characteristics of ant-eating Zodarion spiders (Araneae: Zodariidae): Potential biological control agents. Biological Control 34, 196-203. https://doi.org/10.1016/j.biocontrol.2005.05.008

Pekár, S., Michalko, R., Loverre, P., Líznarová, E., Černecká, L'., 2015. Biological control in winter: novel evidence for the importance of generalist predators. Journal of Applied Ecology 52, 270-279. https://doi.org/10.1111/1365-2664.12363

Persson, L., 1986. Temperature-Induced Shift in Foraging Ability in Two Fish Species, Roach (Rutilus rutilus) and Perch (Perca fluviatilis): Implications for Coexistence between Poikilotherms. Journal of Animal Ecology 55, 829-839. https://doi.org/10.2307/4419

Persson, L., Greenberg, L.A., 1990. Optimal Foraging and Habitat Shift in Perch (Perca Fluviatilis) in a Resource Gradient. Ecology 71, 1699-1713. https://doi.org/10.2307/1937579

Pervez, A., Omkar, 2005. Functional responses of coccinellid predators: An illustration of a logistic approach. Journal of Insect Science 5, 1-6.

Pichlová, R., Vijverberg, J., 2001. A laboratory study of functional response of Leptodora kindtii to some cladoceran species and copepod nauplii. Archiv für Hydrobiologie 529-544. https://doi.org/10.1127/archiv-hydrobiol/150/2001/529

Plaßmann, T., Maier, G., Stich, H.B., 1997. Predation impact of Cyclops vicinus on the rotifer community in Lake Constance in spring. J Plankton Res 19, 1069-1079. https://doi.org/10.1093/plankt/19.8.1069

Poletti, M., Maia, A.H.N., Omoto, C., 2007. Toxicity of neonicotinoid insecticides to Neoseiulus californicus and Phytoseiulus macropilis (Acari: Phytoseiidae) and their impact on functional response to Tetranychus urticae (Acari: Tetranychidae). Biological Control 40, 30-36. https://doi.org/10.1016/j.biocontrol.2006.09.001

Pollack, J.B., Mroch, R.M., Feller, R.J., 2008. Juvenile White Shrimp Litopenaeus setiferus Predation on Macrobenthic and Zooplanktonic Prey. Journal of Shellfish Research 27, 1247-1253. https://doi.org/10.2983/0730-8000-27.5.1247

Porter, K.G., Gerritsen, J., Orcutt, J.D., 1982. The effect of food concentration on swimming patterns, feeding behavior, ingestion, assimilation, and respiration by Daphnia. Limnology and Oceanography 27, 935-949. https://doi.org/10.4319/lo.1982.27.5.0935

Prokopenko, C.M., Turgeon, K., Fryxell, J.M., 2017. Evaluation of alternative prey-, predator-, and ratiodependent functional response models in a zooplankton microcosm. Can. J. Zool. 95, 177-182. https://doi.org/10.1139/cjz-2016-0106

Provencher, L., Coderre, D., 1987. Functional Responses and Switching of $</ \mathrm{i}>$ Tetragnatha laboriosa $</ \mathrm{i}\rangle$ Hentz (Araneae: Tetragnathidae) and Clubiona pikei Gertsh (Araneae: Clubionidae) for the Aphids </i>Rhopalosiphum maidis</i> (Fitch) and Rhopalosiphum padi (L.) (Homoptera: Aphididae). Environ Entomol 16, 1305-1309. https://doi.org/10.1093/ee/16.6.1305

Queiroz, O.S., Ramos, R.S., Gontijo, L.M., Picanço, M.C., 2015. Functional Response of Three Species of Predatory Pirate Bugs Attacking Eggs of Tuta absoluta (Lepidoptera: Gelechiidae). Environ Entomol 44, 246-251. https://doi.org/10.1093/ee/nvu026

Quinn, T.P., Gende, S.M., Ruggerone, G.T., Rogers, D.E., 2003. Density-dependent predation by brown bears (Ursus arctos) on sockeye salmon (Oncorhynchus nerka). Can. J. Fish. Aquat. Sci. 60, 553562. https://doi.org/10.1139/f03-045 
Rabette, C., Thouvenot, A., Lair, N., 1998. Laboratory experiments on trophic relationships and remote detection between two ciliates and Cyclops vicinus vicinus. Hydrobiologia 373, 157-167. https://doi.org/10.1023/A:1017001725062

Rall, B.C., Brose, U., Hartvig, M., Kalinkat, G., Schwarzmüller, F., Vucic-Pestic, O., Petchey, O.L., 2012. Universal temperature and body-mass scaling of feeding rates. Philos. Trans. R. Soc. Lond., B, Biol. Sci. 367, 2923-2934. https://doi.org/10.1098/rstb.2012.0242

Ranta, E., Nuutinen, V., 1985. Foraging by the Smooth Newt (Triturus vulgaris) on Zooplankton: Functional Responses and Diet Choice. Journal of Animal Ecology 54, 275-293. https://doi.org/10.2307/4638

Redpath, S.M., Thirgood, S.J., 1999. Numerical and functional responses in generalist predators: hen harriers and peregrines on Scottish grouse moors. Journal of Animal Ecology 68, 879-892. https://doi.org/10.1046/j.1365-2656.1999.00340.x

Reeve, M.R., Walter, M.A., Ikeda, T., 1978. Laboratory studies of ingestion and food utilization in lobate and tentaculate ctenophores. Limnology and Oceanography 23, 740-751. https://doi.org/10.4319/lo.1978.23.4.0740

Řezáč, M., Pekár, S., Stará, J., 2010. The negative effect of some selective insecticides on the functional response of a potential biological control agent, the spider Philodromus cespitum. BioControl 55, 503-510. https://doi.org/10.1007/s10526-010-9272-3

Rigler, F.H., 1961. The Relation Between Concentration of Food and Feeding Rate of Daphnia Magna Straus. Can. J. Zool. 39, 857-868. https://doi.org/10.1139/z61-080

Rindone, R.R., Eggleston, D.B., 2011. Predator-prey dynamics between recently established stone crabs (Menippe spp.) and oyster prey (Crassostrea virginica). Journal of Experimental Marine Biology and Ecology 407, 216-225. https://doi.org/10.1016/j.jembe.2011.06.018

Rocha, L. da, Redaelli, L.R., 2004. Functional response of Cosmoclopius nigroannulatus (Hem.: Reduviidae) to different densities of Spartocera dentiventris (Hem.: Coreidae) nymphae. Brazilian Journal of Biology 64, 309-316. https://doi.org/10.1590/S1519-69842004000200017

Roche, K., 1990. Prey features affecting ingestion rates by Acanthocyclops robustus (Copepoda: Cyclopoida) on zooplankton. Oecologia 83, 76-82. https://doi.org/10.1007/BF00324637

Rogers, D., 1972. Random Search and Insect Population Models. Journal of Animal Ecology 41, 369-383. https://doi.org/10.2307/3474

Rogerson, A., 1981. The ecological energetics of Amoeba proteus (Protozoa). Hydrobiologia 85, 117. https://doi.org/10.1007/BF00006621

Rohlfs, W.M., Mack, T.P., 1984. Functional Response of Ophion flavidus Brulle (Hymenoptera: Ichneumonidae) Females to Various Densities of Fall Armyworm (Spodoptera frugiperda J. E. Smith) (Lepidoptera: Noctuidae). Environ Entomol 13, 708-710. https://doi.org/10.1093/ee/13.3.708

Rosenbaum, B., Rall, B.C., 2018. Fitting functional responses: Direct parameter estimation by simulating differential equations. Methods in Ecology and Evolution 9, 2076-2090. https://doi.org/10.1111/2041-210X.13039

Rossi, M.N., Reigada, C., Godoy, W.A.C., 2006. The effect of hunger level on predation dynamics in the spider Nesticodes rufipes: a functional response study. Ecol Res 21, 617-623. https://doi.org/10.1007/s11284-006-0159-9

Rothhaupt, K.O., 1990. Changes of the functional responses of the rotifers Brachionus rubens and Brachionus calyciflorus with particle sizes. Limnology and Oceanography 35, 24-32. https://doi.org/10.4319/lo.1990.35.1.0024

Ryer, C.H., Lawton, A., Lopez, R.J., Olla, B.L., 2002. A comparison of the functional ecology of visual vs. nonvisual foraging in two planktivorous marine fishes. Can. J. Fish. Aquat. Sci. 59, 1305-1314. https://doi.org/10.1139/f02-097 
Ryther, J.H., 1954. Inhibitory Effects of Phytoplankton upon the Feeding of Daphnia Magna with Reference to Growth, Reproduction, and Survival. Ecology 35, 522-533. https://doi.org/10.2307/1931041

Saage, A., Vadstein, O., Sommer, U., 2009. Feeding behaviour of adult Centropages hamatus (Copepoda, Calanoida): Functional response and selective feeding experiments. Journal of Sea Research 62, 16-21. https://doi.org/10.1016/j.seares.2009.01.002

Sabaghi, R., Sahragard, A., Hosseini, R., 2011. Functional and numerical responses of Scymnus syriacus Marseul (Coleoptera: Coccinellidae) to the black bean aphid, Aphis fabae Scopoli (Hemiptera: Aphididae) under laboratory conditions. Journal of Plant Protection Research 51, 423-428.

Sahayaraj, K., Ambrose, D.P., 1994. Stage and host preference and functional response of a Reduviid predator Acanthaspis pedestris Stal to four cotton pests. Journal of Biological Control 8, 23-26.

Sahayaraj, K., Kumar, V., Avery, P.B., 2015. Functional response of Rhynocoris kumarii (Hemiptera: Reduviidae) to different population densities of Phenacoccus solenopsis (Hemiptera: Pseudococcidae) recorded in the laboratory. EJE 112, 69-74. https://doi.org/10.14411/eje.2015.020

Saiz, E., Kiørboe, T., 1995. Predatory and suspension feeding of the copepod Acartia tonsa in turbulent environments. Marine Ecology Progress Series 122, 147-158. https://doi.org/10.3354/meps122147

Saleh, A., Ghabeish, I., Al-Zyoud, F., 2010. Functional Response of the Predator Hippodamia variegata ( Goeze ) ( Coleoptera : Coccinellidae ) Feeding on the Aphid Brachycaudus helichrysi ( Kaltenbach ) Infesting Chrysanthemum in the Laboratory. Jordan Journal of Biological Sciences 147, 1-8.

Saljoqi, A.-U.-R., Asad, N., Khan, J., Ehsan-ul-Haq, Nasir, M., Zada, H., Ahmad, B., Nadeem, M., Huma, Z., Salim, M., 2016. Functional Response of Chrysoperla carnea Stephen (Neuroptera: Chrysopidae) Fed on Cabbage Aphid, Brevicoryne brassicae (Linnaeus) Under Laboratory Conditions. Pakistan Journal of Zoology 48, 165-169.

Saljoqi, A.-U.-R., Nasir, M., Khan, J., Ehsan-ul-Haq, Salim, M., Nadeem, M., Huma, Z., Saeed, H.G., Ahmad, B., Zada, H., Rehman, S., 2015. Functional response study of Cryptolaemus montrouzieri Mulsant (Coleoptera: Coccinellidae) fed on Cotton mealy bug, Phenacoccus solenopsis Tinsley under Laboratory Conditions. Journal of Entomology and Zoology Studies 3, 411-415.

Samu, F., Biro, Z., 2013. Functional response, multiple feeding and wasteful killing in a wolf spider (Araneae: Lycosidae). EJE 90, 471-476.

Sandberg, E., 1997. Does oxygen deficiency modify the functional response of Saduria entomon (Isopoda) to Bathyporeia pilosa (Amphipoda)? Marine Biology 129, 499-504. https://doi.org/10.1007/s002270050190

Sandheinrich, M.B., Atchison, G.J., 1989. Sublethal Copper Effects on Bluegill, Lepomis macrochirus, Foraging Behavior. Can. J. Fish. Aquat. Sci. 46, 1977-1985. https://doi.org/10.1139/f89-248

Sandness, J.N., McMurtry, J.A., 1970. Functional response of three species of Phytoseiidae (Acarina) to prey density. The Canadian Entomologist 102, 692-704. https://doi.org/10.4039/Ent102692-6

Sarma, S.S.S., Jimenez-Contreras, J., Fernandez, R., Nandini, S., Garcia-Garcia, G., 2013. Functional responses and feeding rates of Mesocyclops pehpeiensis $\mathrm{Hu}$ (Copepoda) fed different diets (rotifers, cladocerans, alga and cyanobacteria). Journal of Natural History 47, 841-852.

Sarmento, R.A., Pallini, A., Venzon, M., Souza, O.F.F. de, Molina-Rugama, A.J., Oliveira, C.L. de, 2007. Functional response of the predator Eriopis connexa (Coleoptera: Coccinellidae) to different prey types. Brazilian Archives of Biology and Technology 50, 121-126. https://doi.org/10.1590/S1516-89132007000100014

Sarnelle, O., Wilson, A.E., 2008. Type III Functional Response in Daphnia. Ecology 89, 1723-1732. https://doi.org/10.1890/07-0935.1 
Schmidt, J.M., Crist, T.O., Wrinn, K., Rypstra, A.L., 2014. Predator interference alters foraging behavior of a generalist predatory arthropod. Oecologia 175, 501-508. https://doi.org/10.1007/s00442-0142922-x

Seiedy, M., Saboori, A., Allahyari, H., Talaei-Hassanloui, R., Tork, M., 2012. Functional Response of Phytoseiulus persimilis (Acari: Phytoseiidae) on Untreated and Beauveria bassiana - Treated Adults of Tetranychus urticae (Acari: Tetranychidae). J Insect Behav 25, 543-553. https://doi.org/10.1007/s10905-012-9322-z

Seko, T., Miura, K., 2008. Functional response of the lady beetle Harmonia axyridis (Pallas) (Coleoptera: Coccinellidae) on the aphid Myzus persicae (Sulzer) (Homoptera: Aphididae). Applied Entomology and Zoology 43, 341-345. https://doi.org/10.1303/aez.2008.341

Sell, A.F., Keuren, D. van, Madin, L.P., 2001. Predation by omnivorous copepods on early developmental stages of Calanus finmarchicus and Pseudocalanus spp. Limnology and Oceanography 46, 953959. https://doi.org/10.4319/lo.2001.46.4.0953

Sentis, A., Gémard, C., Jaugeon, B., Boukal, D.S., 2017. Predator diversity and environmental change modify the strengths of trophic and nontrophic interactions. Global Change Biology 23, 26292640. https://doi.org/10.1111/gcb.13560

Sentis, A., Hemptinne, J.-L., Brodeur, J., 2012. Using functional response modeling to investigate the effect of temperature on predator feeding rate and energetic efficiency. Oecologia 169, 11171125. https://doi.org/10.1007/s00442-012-2255-6

Sepúlveda, F., Carrillo, R., 2007. Functional response of the predatory mite Chileseius camposi (Acarina: Phytoseiidae) on densities of it prey, Panonychus ulmi (Acarina: Tetranychidae). Revista de Biología Tropical 56. https://doi.org/10.15517/rbt.v56i3.5707

Sharifian, I., Sabahi, Q., Khoshabi, J., 2015. Functional response of Macrolophus pygmaeus (Rambur) and Nesidiocoris tenuis (Reuter) feeding on two different prey species. Archives of Phytopathology and Plant Protection 48, 910-920. https://doi.org/10.1080/03235408.2016.1143579

Shipp, J.L., Whitfield, G.H., 1991. Functional Response of the Predatory Mite, Amblyseius cucumeris (Acari: Phytoseiidae), on Western Flower Thrips, Frankliniella occidentalis (Thysanoptera: Thripidae). Environ Entomol 20, 694-699. https://doi.org/10.1093/ee/20.2.694

Shrestha, G., Enkegaard, A., 2013. The green lacewing, Chrysoperla carnea: Preference between lettuce aphids, Nasonovia ribisnigri, and western flower thrips, Frankliniella occidentalis. J Insect Sci 13. https://doi.org/10.1673/031.013.9401

Shukla, A.N., Singh, R., Tripathi, C.P.M., 1990. Effect of predation period on the functional response of Coccinella septempunctata Linn. (Coleoptera: Coccinellidae), a predator of Lipaphis erysimi Kalt. (Hemiptera: Aphididae). Journal of Advanced Zoology 11, 27-32.

Siddiqui, A., Omkar, D., Paul, S.C., Mishra, G., 2015. Predatory responses of selected lines of developmental variants of ladybird, Propylea dissecta (Coleoptera: Coccinellidae) in relation to increasing prey and predator densities. Biocontrol Science and Technology 25, 992-1010. https://doi.org/10.1080/09583157.2015.1024101

Sing, S.E., Arbogast, R.T., 2008. Predatory response of Xylocoris flavipes to bruchid pests of stored food legumes. Entomologia Experimentalis Et Applicata. 126: 107-114.

Skirvin, D.J., Fenlon, J.S., 2001. Plant species modifies the functional response of Phytoseiulus persimilis (Acari: Phytoseiidae) to Tetranychus urticae (Acari: Tetranychidae): implications for biological control. Bull. Entomol. Res. 91, 61-67.

Smith, R.B., 1984. Aspects of the feeding ecology of the garden cross-spider, Araneus diadematus Clerck. University of British Columbia. https://doi.org/10.14288/1.0096174

Sohrabi, F., Shishehbor, P., 2007. Functional and numerical responses of Stethorus gilvifrons Mulsant feeding on strawberry spider mite, Tetranychus turkestani Ugarov and Nikolski. Pak. J. Biol. Sci. $10,4563-4566$. 
Sokolow, S.H., Lafferty, K.D., Kuris, A.M., 2014. Regulation of laboratory populations of snails (Biomphalaria and Bulinus spp.) by river prawns, Macrobrachium spp. (Decapoda, Palaemonidae): Implications for control of schistosomiasis. Acta Tropica 132, 64-74. https://doi.org/10.1016/j.actatropica.2013.12.013

Soluk, D.A., 1993. Multiple Predator Effects: Predicting Combined Functional Response of Stream Fish and Invertebrate Predators. Ecology 74, 219-225. https://doi.org/10.2307/1939516

Song, Z.-W., Zheng, Y., Zhang, B.-X., Li, D.-S., 2016. Prey consumption and functional response of Neoseiulus californicus and Neoseiulus longispinosus (Acari: Phytoseiidae) on Tetranychus urticae and Tetranychus kanzawai (Acari: Tetranychidae). Systematic and Applied Acarology 21, 936-946. https://doi.org/10.11158/saa.21.7.7

Sørnes, T.A., Aksnes, D.L., 2004. Predation efficiency in visual and tactile zooplanktivores. Limnology and Oceanography 49, 69-75. https://doi.org/10.4319/lo.2004.49.1.0069

Spitze, K., 1985. Functional Response of an Ambush Predator: Chaoborus americanus Predation on Daphnia pulex. Ecology 66, 938-949. https://doi.org/10.2307/1940556

Springett, B.P., Matthiessen, J.N., 1975. Predation on Potato Moth, Phthorimaea operculella (Lepidoptera: Gelechiidae), by the Western Silvereye, Zosterops gouldi (Aves: Zosteropidae). Aust. J. Zool. 23, 65-70. https://doi.org/10.1071/zo9750065

Starkweather, P.L., Gilbert, J.J., 1977. Feeding in the Rotifer Brachionus calyciflorus. II. Effect of Food Density on Feeding Rates Using Euglena gracilis and Rhodotorula glutinis. Oecologia 28, 133139.

Stavrinides, M.C., Skirvin, D.J., 2003. The effect of chrysanthemum leaf trichome density and prey spatial distribution on predation of Tetranychus urticae (Acari: Tetranychidae) by Phytoseiulus persimilis (Acari: Phytoseiidae). Bull. Entomol. Res. 93, 343-350.

Stewart, C.D., Braman, S.K., Pendley, A.F., 2002. Functional Response of the Azalea Plant Bug (Heteroptera: Miridae) and a Green Lacewing Chrysoperla rufilabris (Neuroptera: Chrysopidae), Two Predators of the Azalea Lace Bug (Heteroptera: Tingidae). Environ Entomol 31, 1184-1190. https://doi.org/10.1603/0046-225X-31.6.1184

Stillman, R.A., Simmons, V.L., 2006. Predicting the functional response of a farmland bird. Functional Ecology 20, 723-730. https://doi.org/10.1111/j.1365-2435.2006.01155.x

Sueldo, M.R., Bruzzone, O.A., Virla, E.G., 2010. Characterization of the earwig, Doru lineare, as a predator of larvae of the fall armyworm, Spodoptera frugiperda: A functional response study. J Insect Sci 10. https://doi.org/10.1673/031.010.3801

Sundell, J., Norrdahl, K., Korpimäki, E., Hanski, I., 2000. Functional Response of the Least Weasel, Mustela nivalis nivalis. Oikos 90, 501-508.

Taylor, A.D., 1988. Host Effects on Functional and Ovipositional Responses of Bracon hebetor. Journal of Animal Ecology 57, 173-184. https://doi.org/10.2307/4771

Taylor, D.L., Collie, J.S., 2003. Effect of temperature on the functional response and foraging behavior of the sand shrimp Crangon septemspinosa preying on juvenile winter flounder Pseudopleuronectes americanus. Marine Ecology Progress Series 263, 217-234. https://doi.org/10.3354/meps263217

Tellez, M.D.M., Tapia, G., Gamez, M., Cabello, T., Emden, H.F. van, 2013. Predation of Bradysia sp. (Diptera: Sciaridae), Liriomyza trifolii (Diptera: Agromyzidae) and Bemisia tabaci (Hemiptera: Aleyrodidae) by Coenosia attenuata (Diptera: Muscidae) in greenhouse crops. EJE 106, 199-204. https://doi.org/10.14411/eje.2009.025

Tenhumberg, B., 1995. Estimating Predatory Efficiency of Episyrphus balteatus (Diptera: Syrphidae) in Cereal Fields. Environ Entomol 24, 687-691. https://doi.org/10.1093/ee/24.3.687 
Thompson, D.J., 1978. Towards a Realistic Predator-Prey Model: The Effect of Temperature on the Functional Response and Life History of Larvae of the Damselfly, Ischnura elegans. Journal of Animal Ecology 47, 757-767. https://doi.org/10.2307/3669

Thompson, D.J., 1975. Towards a Predator-Prey Model Incorporating Age Structure: The Effects of Predator and Prey Size on the Predation of Daphnia magna by Ischnura elegans. Journal of Animal Ecology 44, 907-916. https://doi.org/10.2307/3727

Thor, P., Wendt, I., 2010. Functional response of carbon absorption efficiency in the pelagic calanoid copepod Acartia tonsa. Limnology and Oceanography 55, 1779-1789. https://doi.org/10.4319/lo.2010.55.4.1779

Timms, J.E., Oliver, T.H., Straw, N.A., Leather, S.R., 2008. The effects of host plant on the coccinellid functional response: Is the conifer specialist Aphidecta obliterata (L.) (Coleoptera: Coccinellidae) better adapted to spruce than the generalist Adalia bipunctata (L.) (Coleoptera: Coccinellidae)? Biological Control 47, 273-281. https://doi.org/10.1016/j.biocontrol.2008.08.009

Tirelli, V., Mayzaud, P., 2005. Relationship between functional response and gut transit time in the calanoid copepod Acartia clausi: role of food quantity and quality. J Plankton Res 27, 557-568. https://doi.org/10.1093/plankt/fbi031

Titelman, J., Gandon, L., Goarant, A., Nilsen, T., 2007. Intraguild predatory interactions between the jellyfish Cyanea capillata and Aurelia aurita. Mar Biol 152, 745-756. https://doi.org/10.1007/s00227-007-0721-1

Titelman, J., Hansson, L.J., 2006. Feeding rates of the jellyfish Aurelia aurita on fish larvae. Marine Biology 149, 297-306. https://doi.org/10.1007/s00227-005-0200-5

Toscano, B.J., Newsome, B., Griffen, B.D., 2014. Parasite modification of predator functional response. Oecologia 175, 345-352. https://doi.org/10.1007/s00442-014-2905-y

Townsend, C.R., Risebrow, A.J., 1982. The influence of light level on the functional response of a zooplanktonivorous fish. Oecologia 53, 293-295. https://doi.org/10.1007/BF00389002

Trichilo, P.J., Leigh, T.F., 1986. Predation on Spider Mite Eggs by the Western Flower Thrips, Frankliniella occidentalis (Thysanoptera: Thripidae), an Opportunist in a Cotton Agroecosystem. Environ Entomol 15, 821-825. https://doi.org/10.1093/ee/15.4.821

Tully, T., Cassey, P., Ferrière, R., 2005. Functional response: rigorous estimation and sensitivity to genetic variation in prey. Oikos 111, 479-487. https://doi.org/10.1111/j.1600-0706.2005.14062.x

Turnbull, A.L., 1962. Quantitative Studies of the Food of Linyphia triangularis Clerck (Araneae: Linyphiidae). The Canadian Entomologist 94, 1233-1249. https://doi.org/10.4039/Ent941233-12

Twardochleb, L.A., Novak, M., Moore, J.W., 2012. Using the functional response of a consumer to predict biotic resistance to invasive prey. Ecological Applications 22, 1162-1171. https://doi.org/10.1890/11-0871.1

Uiterwaal, S.F., DeLong, J.P., 2018. Multiple factors, including arena size, shape the functional responses of ladybird beetles. Journal of Applied Ecology 55, 2429-2438. https://doi.org/10.1111/13652664.13159

Uiterwaal, S.F., Mares, C., DeLong, J.P., 2017. Body size, body size ratio, and prey type influence the functional response of damselfly nymphs. Oecologia 185, 339-346. https://doi.org/10.1007/s00442-017-3963-8

Uye, S., 1986. Impact of copepod grazing on the red-tide flagellate Chattonella antiqua. Marine Biology 92, 35-43. https://doi.org/10.1007/BF00392743

van den Bosch, F., Santer, B., 1993. Cannibalism in Cyclops abyssorum. Oikos 67, 19-28. https://doi.org/10.2307/3545091

van der Veer, H.W., Bergman, M.J.N., 1987. Predation by crustaceans on a newly settled 0-group plaice Pleuronectes platessa population in the western Wadden Sea. Marine Ecology Progress Series 35, 203-215. 
van Lenteren, J.C., Hemerik, L., Lins, J.C., Bueno, V.H.P., 2016. Functional Responses of Three Neotropical Mirid Predators to Eggs of $</$ i $>$ Tuta absoluta $<i>$ on Tomato. Insects 7. https://doi.org/10.3390/insects7030034

Veeravel, R., Baskaran, P., 1997. Functional and Numerical Responses of Coccinella transversalis Fab. and Cheilomenes sexmaculatus Fab. Feeding on the Melon Aphid, Aphis gossypii Glov. International Journal of Tropical Insect Science 17, 335-339. https://doi.org/10.1017/S1742758400019159

Vega, M.P.A., 1997. The functional response of copepodid stages to adult of Parabroteas sarsi (Copepoda, Calanoida). Internationale Revue der gesamten Hydrobiologie und Hydrographie 82, 95-105. https://doi.org/10.1002/iroh.19970820112

Verity, P.G., 1991. Measurement and simulation of prey uptake by marine planktonic ciliates fed plastidic and aplastidic nanoplankton. Limnology and Oceanography 36, 729-750. https://doi.org/10.4319/lo.1991.36.4.0729

Vinyard, G.L., Menger, R.A., 1980. Chaoborus americanus predation on various zooplankters; Functional response and behavioral observations. Oecologia 45, 90-93. https://doi.org/10.1007/BF00346712

Vollset, K.W., Bailey, K.M., 2011. Interplay of individual interactions and turbidity affects the functional response of three-spined sticklebacks Gasterosteus aculeatus. Journal of Fish Biology 78, 19541964. https://doi.org/10.1111/j.1095-8649.2011.02963.x

Von Westernhagen, H., Rosenthal, H., 1976. Predator-Prey Relationship Between Pacific Herring, Clupea harengus pallasi, Larvae and a Predatory Hyperiid Amphipod, Hyperoche medusarum. Fishery Bulletin 74, 669-674.

Vucetich, J.A., Peterson, R.O., Schaefer, C.L., 2002. The Effect of Prey and Predator Densities on Wolf Predation. Ecology 83, 3003-3013. https://doi.org/10.1890/00129658(2002)083[3003:TEOPAP]2.0.CO;2

Vucic-Pestic, O., Birkhofer, K., Rall, B.C., Scheu, S., Brose, U., 2010. Habitat structure and prey aggregation determine the functional response in a soil predator-prey interaction. Pedobiologia 53, 307-312. https://doi.org/10.1016/j.pedobi.2010.02.003

Walker, S.E., Rypstra, A.L., 2002. Sexual dimorphism in trophic morphology and feeding behavior of wolf spiders (Araneae: Lycosidae) as a result of differences in reproductive roles. Can. J. Zool. 80, 679-688. https://doi.org/10.1139/z02-037

Walker, S.E., Rypstra, A.L., 2001. Sexual Dimorphism in Functional Response and Trophic Morphology in Rabidosa rabida (Araneae: Lycosidae). The American Midland Naturalist 146, 161-170. https://doi.org/10.1674/0003-0031(2001)146[0161:SDIFRA]2.0.CO;2

Ware, D.M., 1972. Predation by Rainbow Trout (Salmo gairdneri): the Influence of Hunger, Prey Density, and Prey Size. J. Fish. Res. Bd. Can. 29, 1193-1201. https://doi.org/10.1139/f72-175

Wasserman, R.J., Alexander, M.E., Dalu, T., Ellender, B.R., Kaiser, H., Weyl, O.L.F., 2016a. Using functional responses to quantify interaction effects among predators. Functional Ecology 30, 1988-1998. https://doi.org/10.1111/1365-2435.12682

Wasserman, R.J., Alexander, M.E., Weyl, O.L.F., Barrios-O'Neill, D., Froneman, P.W., Dalu, T., $2016 b$. Emergent effects of structural complexity and temperature on predator-prey interactions. Ecosphere 7, e01239. https://doi.org/10.1002/ecs2.1239

Wei, Q., Walde, S.J., 1997. The functional response of Typhlodromus pyri to its prey, Panonychus ulmi: the effect of pollen. Exp Appl Acarol 21,677-684. https://doi.org/10.1023/A:1018460719344

Weisse, T., 2004. Meseres corlissi: a rare oligotrich ciliate adapted to warm water and temporary habitats. Aquatic Microbial Ecology 37, 75-83. https://doi.org/10.3354/ame037075 
Weisse, T., Frahm, A., 2002. Direct and indirect impact of two common rotifer species (Keratella spp.) on two abundant ciliate species (Urotricha furcata, Balanion planctonicum). Freshwater Biology 47, 53-64. https://doi.org/10.1046/j.1365-2427.2002.00780.x

Weisse, T., Karstens, N., Meyer, V.C.L., Janke, L., Lettner, S., Teichgräber, K., 2001. Niche separation in common prostome freshwater ciliates: the effect of food and temperature. Aquatic Microbial Ecology 26, 167-179. https://doi.org/10.3354/ame026167

Wellington, C.G., Mayer, C.M., Bossenbroek, J.M., Stroh, N.A., 2010. Effects of turbidity and prey density on the foraging success of age 0 year yellow perch Perca flavescens. Journal of Fish Biology 76, 1729-1741. https://doi.org/10.1111/j.1095-8649.2010.02612.x

Wells, M.L., McPherson, R.M., 1999. Population Dynamics of Three Coccinellids in Flue-Cured Tobacco and Functional Response of Hippodamia convergens (Coleoptera: Coccinellidae) Feeding on Tobacco Aphids (Homoptera: Aphididae). Environ Entomol 28, 768-773. https://doi.org/10.1093/ee/28.4.768

Wennhage, H., 2002. Vulnerability of newly settled plaice (Pleuronectes platessa L.) to predation: effects of habitat structure and predator functional response. Journal of Experimental Marine Biology and Ecology 269, 129-145. https://doi.org/10.1016/S0022-0981(02)00005-9

Wickham, S.A., 1995. Cyclops predation on ciliates: species.specific differences and functional responses. J Plankton Res 17, 1633-1646. https://doi.org/10.1093/plankt/17.8.1633

Wiedenmann, R.N., O'Neil, R.J., 1991. Laboratory Measurement of the Functional Response of Podisus maculiventris (Say) (Heteroptera: Pentatomidae). Environ Entomol 20, 610-614. https://doi.org/10.1093/ee/20.2.610

Williamson, C.E., 1984. Laboratory and field experiments on the feeding ecology of the cyclopoid copepod, Mesocyclops edax. Freshwater Biology 14, 575-585. https://doi.org/10.1111/j.13652427.1984.tb00177.x

Winkler, H., Orellana, C.P., 1992. Functional responses of five cyprinid species to planktonic prey. Environ Biol Fish 33, 53-62. https://doi.org/10.1007/BF00002553

Witz, B.W., 1996. The Functional Response of Cnemidophorus sexlineatus: Laboratory versus Field Measurements. Journal of Herpetology 30, 498-506. https://doi.org/10.2307/1565692

Wong, M.C., Barbeau, M.A., 2006. Rock crab predation of juvenile sea scallops: the functional response and its implications for bottom culture. Aquacult Int 14, 355-376. https://doi.org/10.1007/s10499-005-9038-6

Wood, C.C., Hand, C.M., 1985. Food-searching behaviour of the common merganser (Mergus merganser) I: Functional responses to prey and predator density. Can. J. Zool. 63, 1260-1270. https://doi.org/10.1139/z85-189

Wright, R.A., Crowder, L.B., Martin, T.H., 1993. The effects of predation on the survival and sizedistribution of estuarine fishes: an experimental approach. Environ Biol Fish 36, 291-300. https://doi.org/10.1007/BF00001725

Xiao, Y., Fadamiro, H.Y., 2010. Functional responses and prey-stage preferences of three species of predacious mites (Acari: Phytoseiidae) on citrus red mite, Panonychus citri (Acari:

Tetranychidae). Biological Control 53, 345-352. https://doi.org/10.1016/j.biocontrol.2010.03.001

Xue, Y., Bahlai, C.A., Frewin, A., Sears, M.K., Schaafsma, A.W., Hallett, R.H., 2009. Predation by Coccinella septempunctata and Harmonia axyridis (Coleoptera: Coccinellidae) on Aphis glycines (Homoptera: Aphididae). Environmental Entomology 38, 708-714. https://doi.org/10.1603/022.038.0322

Yaşar, B., Ozger, S., 2005. Functional response of Oenopia conglobata (L.) (Coleoptera: Coccinellidae) on Hyalopterus pruni (Geoffroy) (Homoptera: Aphididae) in three different size arenas. Turkiye Entomoloji Dergisi 29, 91-99. 
Yaşar, B., Özger, Ş., 2005. Development, feeding and reproduction responses of Adalia fasciatopunctata revelierei (Mulsant) (Coleoptera: Coccinellidae) to Hyalopterus pruni (Geoffroy) (Homoptera: Aphididae). J Pest Sci 78, 199-203. https://doi.org/10.1007/s10340-005-0089-2

Yen, J., 1991. Predatory feeding behavior of an Antarctic marine copepod, Euchaeta antarctica. Polar Research 10, 433-442. https://doi.org/10.1111/j.1751-8369.1991.tb00664.x

Yen, J., 1987. Predation by a carnivorous marine copepod, Euchaeta norvegica Boeck, on eggs and larvae of the North Atlantic cod Gadus morhua L. Journal of Experimental Marine Biology and Ecology 112, 283-296. https://doi.org/10.1016/0022-0981(87)90074-8

Yoo, Y.D., Seong, K.A., Kim, H.S., Jeong, H.J., Yoon, E.Y., Park, J., Kim, J.I., Shin, W., Palenik, B., 2018 a. Feeding and grazing impact by the bloom-forming euglenophyte Eutreptiella eupharyngea on marine eubacteria and cyanobacteria. Harmful Algae 73, 98-109. https://doi.org/10.1016/j.hal.2018.02.003

Yoo, Y.D., Seong, K.A., Kim, J.S., Nam, S.W., Jeong, H.J., Rho, J.-R., Yih, W., Kim, H.S., 2018b. Mixotrophy in the sand-dwelling dinoflagellate Thecadinium kofoidii. Marine Biology Research 14, 165-172. https://doi.org/10.1080/17451000.2017.1379604

Zarghami, S., Mossadegh, M.S., Kocheili, F., Allahyari, H., Rasekh, A., 2016. Functional Responses of Nephus arcuatus Kapur (Coleoptera: Coccinellidae), the Most Important Predator of Spherical Mealybug Nipaecoccus viridis (Newstead). Psyche: A Journal of Entomology 2016. https://doi.org/10.1155/2016/9417496

Zhang, S.-C., Zhu, F., Zheng, X.-L., Lei, C.-L., Zhou, X.-M., 2013. Survival and developmental characteristics of the predatory bug Orius similis (Hemiptera: Anthocoridae) fed on Tetranychus cinnabarinus (Acari: Tetranychidae) at three constant temperatures. EJE 109, 503-508. https://doi.org/10.14411/eje.2012.063

Zhang, Z.-Q., 1992. Functional response of Allothrombium pulvinum deutonymphs (Acari: Trombidiidae) on two-spotted spider mites (Acari: Tetranychidae). Exp Appl Acarol 15, 249-257. https://doi.org/10.1007/BF01246566 
bioRxiv preprint doi: https://doi.org/10.1101/503334; this version posted December 26,2018 . The copyright holder for this preprint (which was not certified by peer review) is the author/funder, who has granted bioRxiv a license to display the preprint in perpetuity. It is made available under aCC-BY-NC 4.0 International license.

Figure 1. Flow diagram detailing the decisions for how to include and standardize functional response data from the literature.


*When data was presented in both tables and figures, we used data from tables.

Medians and $95 \%$ quantiles of
parameter distributions recorded as
estimate and confidence intervals.

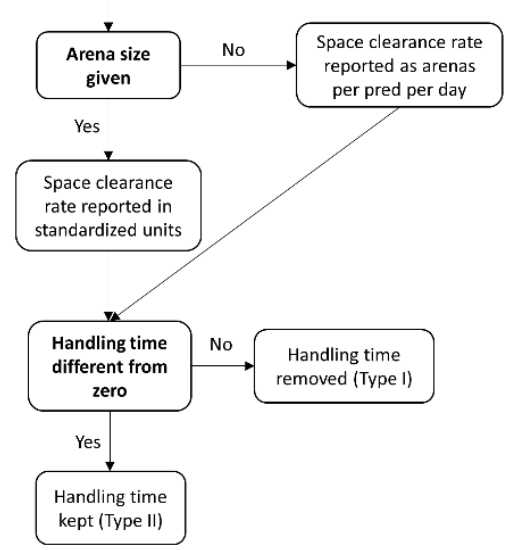


Figure 2. Taylor power law relationship between mean foraging rate and the standard error of the mean across all observations. This relationship was used to estimate the foraging rate standard error for studies where only the mean foraging rate at a resource level was given.

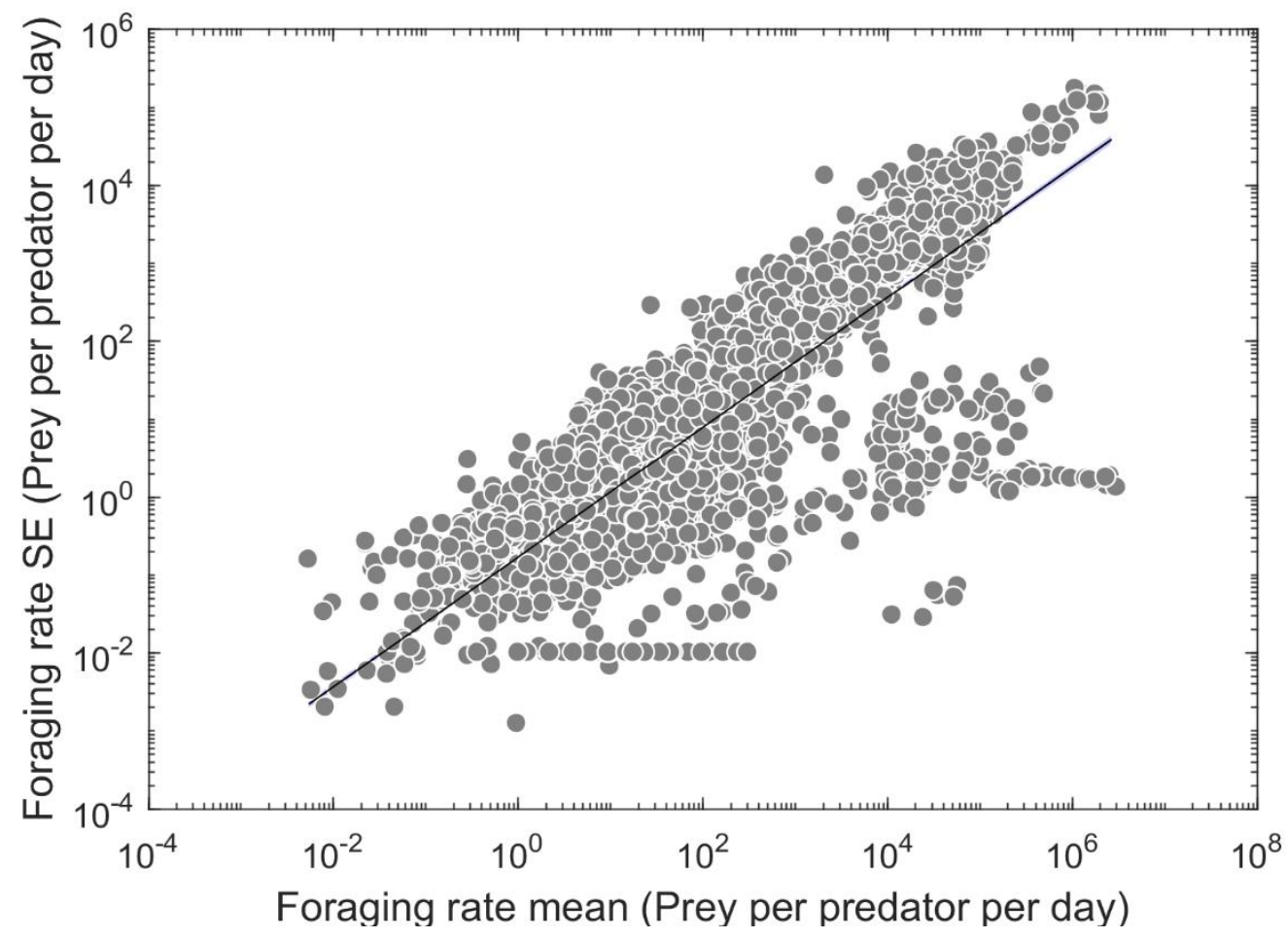


bioRxiv preprint doi: https://doi.org/10.1101/503334; this version posted December 26,2018 . The copyright holder for this preprint (which was not certified by peer review) is the author/funder, who has granted bioRxiv a license to display the preprint in perpetuity. It is made available under aCC-BY-NC 4.0 International license.

Figure 3. Flow diagram detailing the methods for obtaining body masses of consumers and resources represented in functional response data in the FoRAGE database.

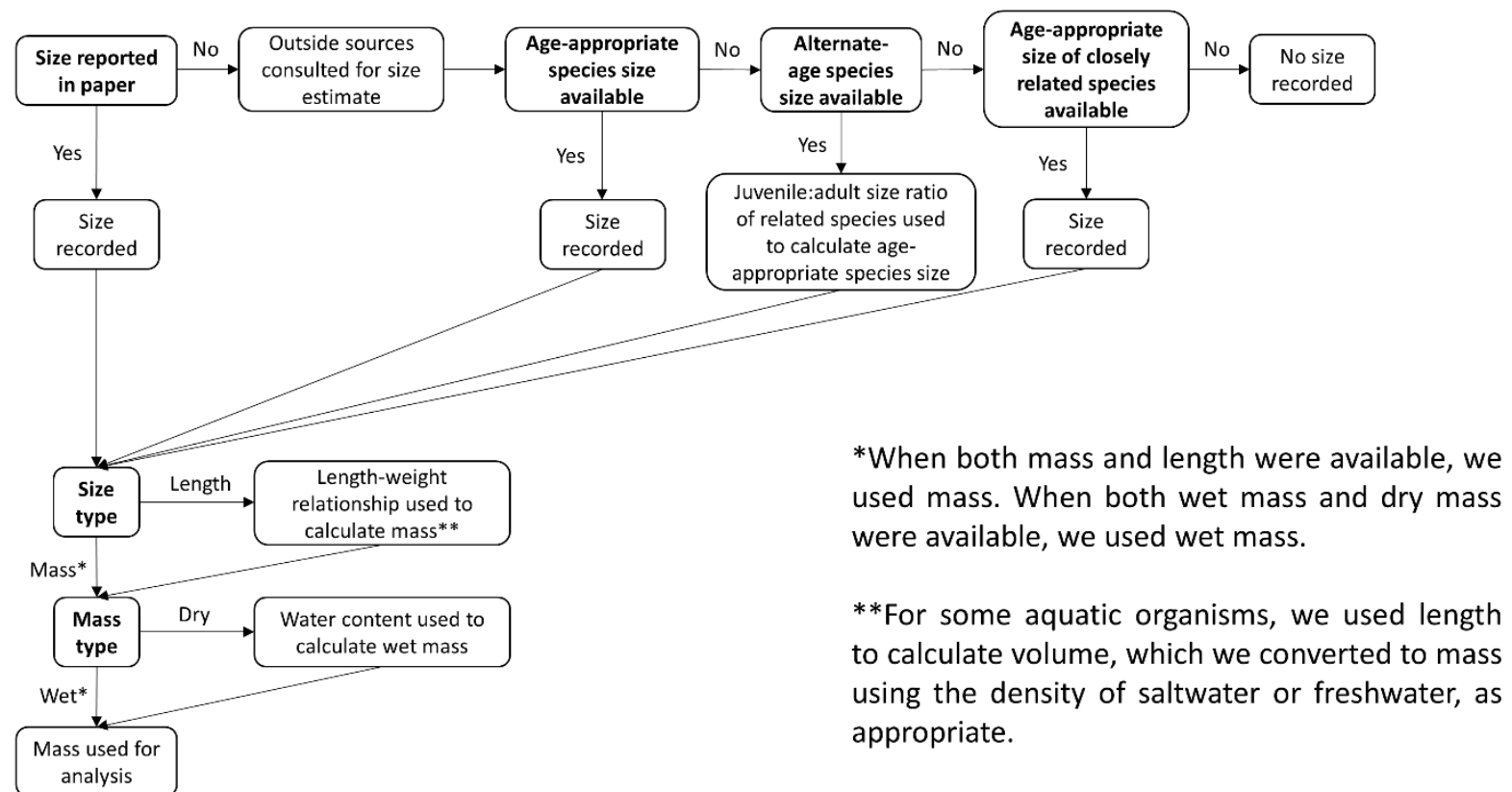


Figure 4. Pie charts showing the breakdown of functional responses in the FoRAGE database by A) habitat, B) foraging type, C) predator major grouping, and minor groupings within the major groupings, connected by lines, for D) invertebrates, E) protozoa, and F) vertebrates.
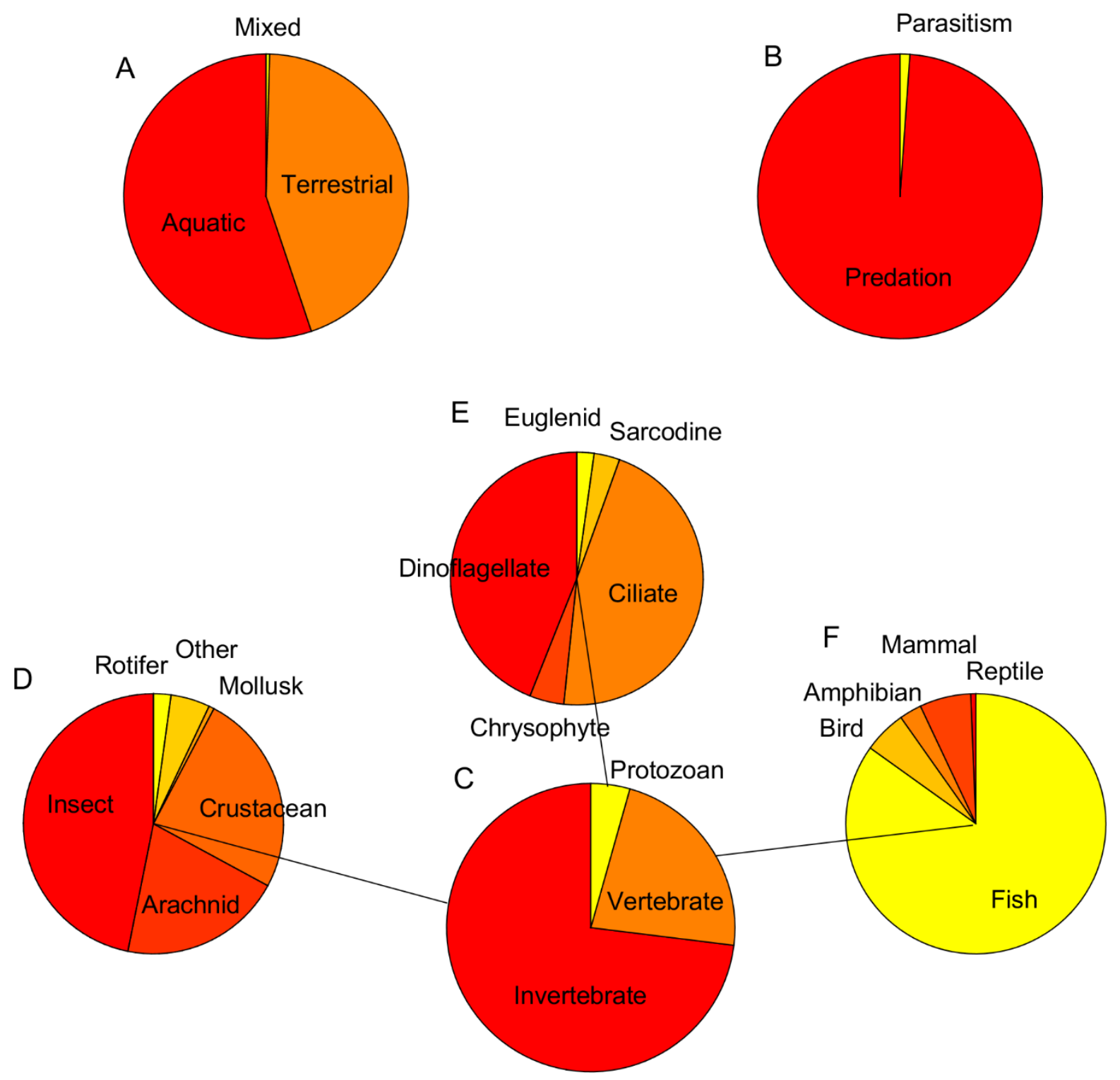
Appendix A: Publications containing original data on the functional responses in the FoRAGE database. Sources are grouped by Predator Major or Minor group.

\begin{tabular}{|c|c|}
\hline $\begin{array}{l}\text { Predator major } \\
\text { or minor group }\end{array}$ & Sources \\
\hline Insect & 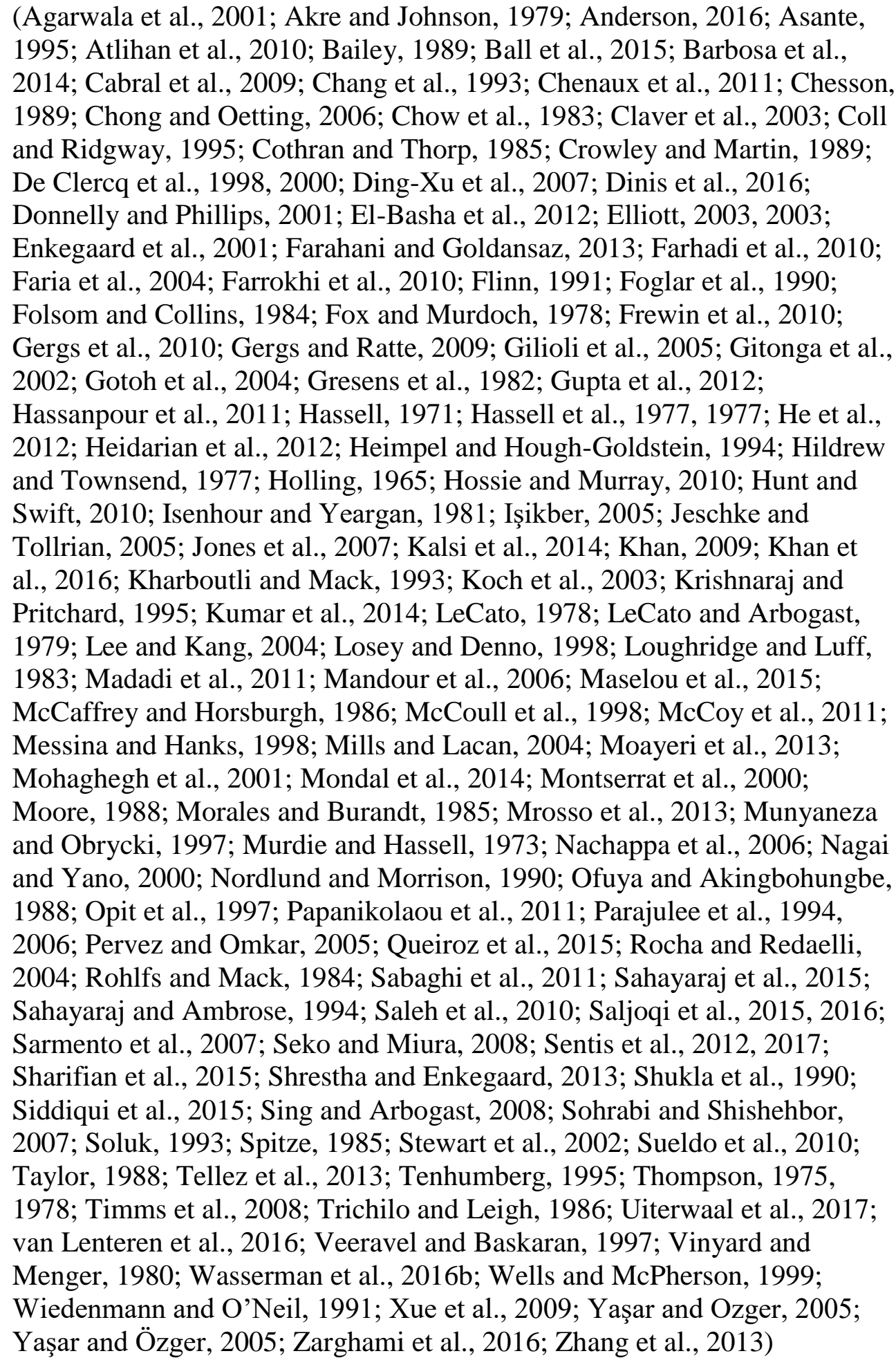 \\
\hline
\end{tabular}




\begin{tabular}{|c|c|}
\hline Mite & $\begin{array}{l}\text { (Badii et al., 2004; Carrillo and Peña, 2012; Castagnoli and Simoni, 1999; } \\
\text { Cédola et al., 2001; Chant, 1961; Everson, 1979; Fan and Petitt, 1994; } \\
\text { Fantinou et al., 2012; Farazmand et al., 2012; Ferla et al., 2011; Fernando } \\
\text { and Hassell, 1980; Gotoh et al., 2004; Hardman and Rogers, 1991; Hauzy et } \\
\text { al., 2010; Hoque et al., 2010; Jafari et al., 2012; Kasap and Atlihan, 2011; } \\
\text { Koveos and Broufas, 2000; Kustutan and Cakmak, 2009; Laing and Osborn, } \\
\text { 1974; Madadi et al., 2007; Midthassel et al., 2014; Nwilene and Nachman, } \\
\text { 1996; Poletti et al., 2007; Sandness and McMurtry, 1970; Seiedy et al., } \\
\text { 2012; Sepúlveda and Carrillo, 2007; Shipp and Whitfield, 1991; Skirvin and } \\
\text { Fenlon, 2001; Stavrinides and Skirvin, 2003; Wei and Walde, 1997; Xiao } \\
\text { and Fadamiro, 2010; Zhang, 1992) }\end{array}$ \\
\hline Cladoceran & $\begin{array}{l}\text { (Burns and Rigler, 1967; DeMott, 1982; Lampert, 1994; McMahon and } \\
\text { Rigler, 1965; Paulsson, n.d.; Pichlová and Vijverberg, 2001; Porter et al., } \\
\text { 1982; Rigler, 1961; Ryther, 1954; Sarnelle and Wilson, 2008) }\end{array}$ \\
\hline $\begin{array}{l}\text { Other } \\
\text { Crustaceans }\end{array}$ & $\begin{array}{l}\text { (Alexander et al., 2012, 2013a, 2013b; Aljetlawi et al., 2004; Andresen and } \\
\text { van der Meer, 2010; Barrios-O’Neill et al., 2014; Bergström and Englund, } \\
\text { 2004; Bollache et al., 2008; Bovy et al., 2015; Chigbu and Sibley, 1994; } \\
\text { Daly and Long, 2014; DeBlois and Leggett, 1991; Dick et al., 2013; } \\
\text { Dumont et al., 1994; Eggleston et al., 1992; Eggleston, 1990a, 1990b, } \\
\text { 1990c; Fitzsimons et al., 2006; Gonçalves et al., 2016; Griffen and Delaney, } \\
\text { 2007; Haddaway et al., 2012; Iribarne et al., 1995; Laverty et al., 2015; } \\
\text { Long et al., 2012; Long and Whitefleet-Smith, 2013; MacNeil et al., 2013; } \\
\text { Moksnes et al., 1997; Pollack et al., 2008; Prokopenko et al., 2017; Rindone } \\
\text { and Eggleston, 2011; Sandberg, 1997; Sokolow et al., 2014; Taylor and } \\
\text { Collie, 2003; Toscano et al., 2014; Twardochleb et al., 2012; van der Veer } \\
\text { and Bergman, 1987; Von Westernhagen and Rosenthal, 1976; Wennhage, } \\
\text { 2002; Wong and Barbeau, 2006) }\end{array}$ \\
\hline Reptile & (Dor et al., 2014; Witz, 1996) \\
\hline Mammal & $\begin{array}{l}\text { (Dale et al., 1994; Gilg et al., 2006; Holling, 1959b, 1965; Messier, 1994; } \\
\text { Nilsen et al., 2009; O’Donoghue et al., 1998; Quinn et al., 2003; Sundell et } \\
\text { al., 2000; Vucetich et al., 2002) }\end{array}$ \\
\hline Mollusk & $\begin{array}{l}\text { (Geange and Stier, 2010; Katz, 1985; Kushner and Hovel, 2006; Márquez et } \\
\text { al., 2007a, 2007b) }\end{array}$ \\
\hline Amphibian & (Anderson et al., 2016; Ranta and Nuutinen, 1985) \\
\hline Spider & $\begin{array}{l}\text { (Bressendorff and Toft, 2011; Denno et al., 2004, 2003; Finke and Denno, } \\
\text { 2002; Hardman and Turnbull, 1980, 1974; Heong et al., 1991; Khan, 2013, } \\
\text { 2012; Líznarová and Pekár, 2013; Lyon et al., 2018; Mansour and } \\
\text { Heimbach, 1993; Michalko and Pekár, 2017; Monzó et al., 2009; } \\
\text { Palanichamy, 1983; Pekár, 2005; Pekár et al., 2015; Provencher and } \\
\text { Coderre, 1987; Rezáč et al., 2010; Rossi et al., 2006; Samu and Biro, 2013; } \\
\text { Schmidt et al., 2014; Smith, 1984; Song et al., 2016; Tully et al., 2005; } \\
\text { Turnbull, 1962; Vucic-Pestic et al., 2010; Walker and Rypstra, 2002, 2001) }\end{array}$ \\
\hline Copepod & $\begin{array}{l}\text { (Almeda et al., 2010; Brandl, 1998; Colin and Dam, 2007; Confer, 1971; } \\
\text { Enriquez-Garcia et al., 2013; Frost, 1972; Garrido et al., 2013; Hada and } \\
\text { Uye, 1991; Hansen et al., 1990; Helenius and Saiz, 2017; Hooff and } \\
\text { Bollens, 2004; Houde and Roman, 1987; Isari and Saiz, 2011; Jeong et al., }\end{array}$ \\
\hline
\end{tabular}




\begin{tabular}{|c|c|}
\hline & $\begin{array}{l}\text { 2007b; Krylov, 1988; Kumar and Rao, 2003; Lampitt, 1978; López-Urrutia } \\
\text { et al., 2004; McQueen, 1969; Morozov et al., 2008; Muschiol et al., 2008a, } \\
\text { 2008b; Nejstgaard et al., 1995; Novich et al., 2014; Olsen et al., 2000; } \\
\text { Plaßmann et al., 1997; Rabette et al., 1998; Roche, 1990; Saage et al., 2009; } \\
\text { Saiz and Kiørboe, 1995; Sarma et al., 2013; Sell et al., 2001; Thor and } \\
\text { Wendt, 2010; Tirelli and Mayzaud, 2005; Uye, 1986; van den Bosch and } \\
\text { Santer, 1993; Vega, 1997; Wickham, 1995; Williamson, 1984; Yen, 1987, } \\
\text { 1991) }\end{array}$ \\
\hline Rotifer & $\begin{array}{l}\text { (Iyer and Rao, 1996; Korstad et al., 1989; Nandini and Sarma, 1999; } \\
\text { Rothhaupt, 1990; Starkweather and Gilbert, 1977; Weisse and Frahm, 2002) }\end{array}$ \\
\hline Fish & $\begin{array}{l}\text { (Alanis et al., 2009; Alexander et al., 2014, 2015; Anderson et al., 1978; } \\
\text { Anderson, 2001; Barnhisel and Kerfoot, 2004; Barrios-O’Neill et al., 2014; } \\
\text { Bergman, 1987, 1988; Bryan et al., 1995; Buckel and Stoner, 2000; Cowan } \\
\text { et al., 2016; Czesny et al., 2001; de Figueiredo et al., 2007; de Villemereuil } \\
\text { and López-Sepulcre, 2011; Fitzsimons et al., 2006; Galarowicz and Wahl, } \\
\text { 2005; Gibson and Ezzi, 1992; Gulbrandsen, 1991; Gustafsson et al., 2010; } \\
\text { Harborne, 2012; Hedgespeth et al., 2014; Hjelm and Johansson, 2003; } \\
\text { Houde and Schekter, 1980; Hyatt, 1980; Johansson and Leonardsson, 1998; } \\
\text { Johansson, 1987; Johnson, 2006; Koski and Johnson, 2002; Kroetz and } \\
\text { Powers, 2015; Letcher et al., 1997; Ljunggren and Sandström, 2007; Miller } \\
\text { et al., 1992; Morales-Ventura et al., 2004; Moss and Beauchamp, 2007; } \\
\text { Moustahfid et al., 2010, 2010; Munk, 1995; Munk and Kiøboe, 1985; } \\
\text { Murdoch et al., 1975; Murray et al., 2013, 2016; O’Brien et al., 2001; } \\
\text { Ohlberger et al., 2008; Oyugi et al., 2012; Persson, 1986; Persson and } \\
\text { Greenberg, 1990; Ryer et al., 2002; Sandheinrich and Atchison, 1989; } \\
\text { Soluk, 1993; Sørnes and Aksnes, 2004; Townsend and Risebrow, 1982; } \\
\text { Vollset and Bailey, 2011; Ware, 1972; Wasserman et al., 2016a; Wellington } \\
\text { et al., 2010; Winkler and Orellana, 1992; Wright et al., 1993) }\end{array}$ \\
\hline Ctenophora & $\begin{array}{l}\text { (Båmstedt, 1998; Buecher and Gasser, 1998; Greene et al., 1986; Jaspers et } \\
\text { al., 2011; Kremer et al., 1986; Monteleone and Duguay, 1988; Reeve et al., } \\
\text { 1978; Sørnes and Aksnes, 2004) }\end{array}$ \\
\hline Cnidarea & $\begin{array}{l}\text { (Bailey and Batty, 1983; Båmstedt, 1990; Båmstedt et al., 1994; Lafontaine } \\
\text { and Leggett, 1988, 1987; Morand et al., 1987; Titelman et al., 2007; } \\
\text { Titelman and Hansson, 2006) }\end{array}$ \\
\hline Bird & $\begin{array}{l}\text { (Fritz et al., 2001; Gilg et al., 2006; Korpimaki and Norrdahl, 1991; Nielsen, } \\
\text { 1999; Redpath and Thirgood, 1999; Springett and Matthiessen, 1975; } \\
\text { Stillman and Simmons, 2006; Wood and Hand, 1985) }\end{array}$ \\
\hline Tardigrade & (Hohberg and Traunspurger, 2005) \\
\hline Platyhelminthes & (Beier et al., 2004; Hammill et al., 2010; Kratina et al., 2007) \\
\hline Chromista & (Hansen and Nielsen, 1997) \\
\hline Protozoa & $\begin{array}{l}\text { (Buskey et al., 1994; Frangópulos et al., 2011; Gismervik, 2005; Hansen, } \\
\text { 1992; Hewett, 1980; Jacobson and Anderson, 1993; Jakobsen and Hansen, } \\
\text { 1997; Jeong et al., 1999; Hae Jin Jeong et al., 2001; H. J. Jeong et al., 2001; } \\
\text { Jeong et al., 2002, 2004, 2007b, 2007a, 2007c, 2011, 2018a, 2018b; Jeong } \\
\text { and Latz, 1994; John and Davidson, 2001; Kamiyama, 1997; Kamiyama et } \\
\text { al., 2005; Kim and Jeong, 2004; Kimmance et al., 2006; Kopp and Tollrian, }\end{array}$ \\
\hline
\end{tabular}


bioRxiv preprint doi: https://doi.org/10.1101/503334; this version posted December 26,2018 . The copyright holder for this preprint (which was not certified by peer review) is the author/funder, who has granted bioRxiv a license to display the preprint in perpetuity. It is made available under aCC-BY-NC 4.0 International license.

\begin{tabular}{|l|l|}
\hline & $\begin{array}{l}\text { 2003; Laybourn, 1976; Lim et al., 2018; Lin et al., 2004; Müller and } \\
\text { Schlegel, 1999; Rogerson, 1981; Verity, 1991; Weisse et al., 2001; Weisse, } \\
\text { 2004; Yoo et al., 2018a, 2018b) }\end{array}$ \\
\hline Plant & (Englund and Harms, 2001) \\
\hline
\end{tabular}

